\title{
The Development of an Astrological Term - from Greek hairesis to Arabic hayyiz
}

\section{Giuseppe Bezza}

\begin{abstract}
The purpose of this paper is to present the history of an astrological technical term, hairesis in Greek and hayyiz in Arabic (often called 'sect' in English). Every scholar is fully aware of the importance and the necessity of a reliable lexicon of astrological terminology. Moreover, it is important to understand the meaning of these astrological terms, which are so numerous and manifold, within an historical context.
\end{abstract}

Aigefors (hairesis) is one of the technical terms which we find outside the narrow field of Greek astrological literature. Plotinus, for example, says about the distinction between diurnal and nocturnal planets:

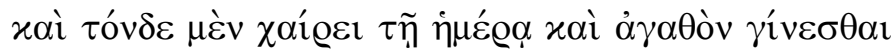

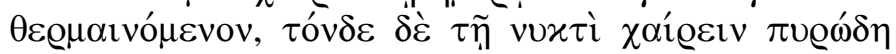
öv $\tau \alpha \ldots$

One of them rejoices by day and becomes good through being warmed up, while the other, of fiery nature, rejoices at night...

Here Plotinus uses the verb $\chi \alpha$ í@eıv (chairein), which is, as we shall see later, a technical astrological term strictly related to the notion of aígers. The origin of this notion must be very ancient, because some

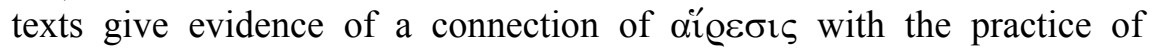
hepatoscopy. Like the liver of a human being, that of a sacrificed animal is 'a mirror which receives likenesses of objects and returns their images to the sight. ${ }^{2}$ It has both sweetness and bitterness: when the bitter

\footnotetext{
${ }^{1}$ Enneads II, 3.5.

${ }^{2}$ Plato, Timceus, $71 \mathrm{~b}-\mathrm{d}$.
}

Giuseppe Bezza, 'The Development of an Astrological Term - from Greek hairesis to Arabic hayyiz', Culture And Cosmos, Vol. 11 no 1 and 2, Spring/Summer and Autumn/Winter 2007 pp. 229-260.

www.CultureAndCosmos.com 
element pervades the liver, it produces the two kinds of bile, but when its natural sweetness prevails, it acquires the ability to practise divination in sleep. The two biles are the black bile, which causes gloominess and the yellow one, which causes choler and anger. The former, astrologers say, is related to Saturn, the latter to Mars. Then, the priest appointed to the examine the liver could easily give a prediction, provided that the entrails are of a good colour and condition. This is the case, Hephæstio of Thebes tells us, ${ }^{3}$ when the Moon is increasing in number and light and applies to beneficent stars. On the other hand, when the Moon is waning and is with Saturn, the entrails are livid, pale, and a watery colour; and when it is waxing and applies to Mars, the entrails are full of reddish spots. But when the Moon, in waxing, applies to Saturn, and in waning applies to Mars above the earth, the entrails are of a good complexion, and bode good fortune. It is the opposite when they are under the earth, especially with maleficent stars.

This text, like others on the foundation of temples or the casting of statues, shows us a hieratic ritual and testifies to the theurgic function of astrology in the Hellenistic world. The examination of the entrails $\left(\sigma \pi \lambda \alpha \gamma \chi v 0 \sigma x o \pi^{\prime} \alpha\right)$, Hephæstio says, is not different from the judgment

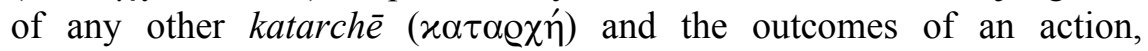
favourable or unfavourable, are similar to the bad or good conditions of the liver of the sacrificed animal. In fact, the two different configurations of the Moon with Saturn and Mars are carefully noted in the composition of Greek ephemerides. Delambre ${ }^{4}$ first drew attention to a small treatise

${ }^{3}$ Apotelesmatica III, 6; Pingree I, p. 253.5; Epitoma IV, 81; Pingree II, pp. 284-

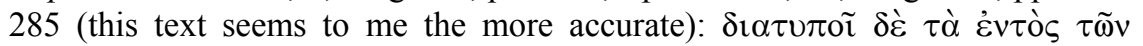

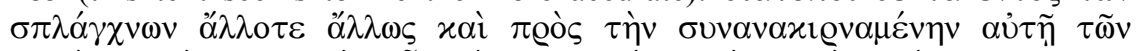

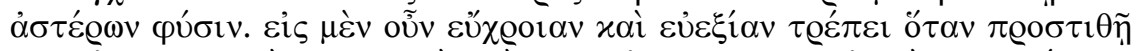

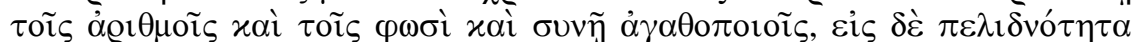

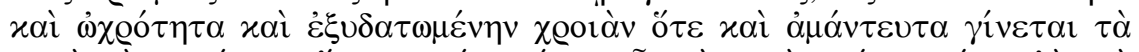

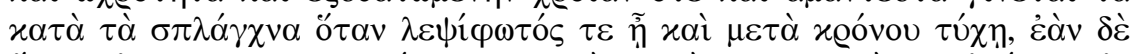

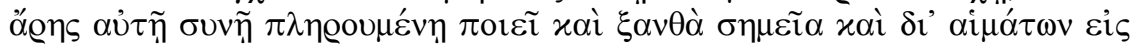

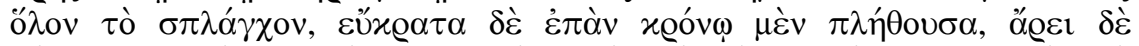

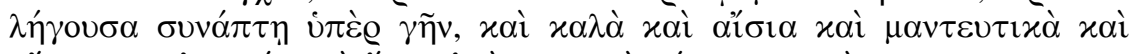

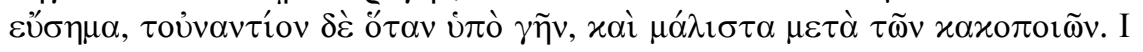
have paraphrased this above.

${ }^{4}$ J. B. J. Delambre, Histoire de l'astronomie ancienne (2 vols, Paris, 1817), II, pp. 635-38. Cf. O. Neugebauer, A History of Ancient Mathematical Astronomy (Berlin, Heidelberg, New York, 1975), pp. 1055-56. 
which he found in a Byzantine manuscript ${ }^{5}$ at the end of Theon's Small Commentary to the Handy Tables, where instructions are given on how an ephemeris should be laid out. The treatise gives some prescriptions about the the conditions of the aspects of the Moon to the Sun and the planets. Afterwards, this remark follows:

$\pi \varepsilon @ i \quad \tau \widetilde{\omega} v \quad \dot{\alpha} \pi \grave{o} \quad \tau \tilde{\omega} v \quad \sigma \chi \eta \mu \alpha \tau 1 \sigma \mu \widetilde{\omega} v \quad \tau \tilde{\eta} \varsigma \quad \sigma \varepsilon \lambda \eta \dot{\eta} v \eta \varsigma$

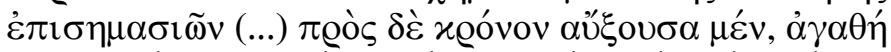

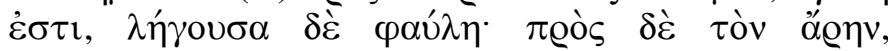

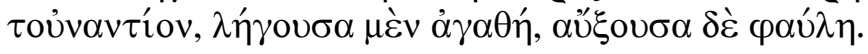

About the indications from the configurations of the Moon (...) the Moon towards Saturn, when it is waxing, is good, when waning is bad; towards Mars, the contrary: it is good when it is waning and bad when waxing. ${ }^{6}$

${ }^{5}$ Par. gr. 2394 (CCAG 8/4 no. 78, p. 20). The text has been edited by Halma in: Tables Manuelles astronomiques de Ptolemée et de Théon, troisième partie (Paris, 1825), pp. 38-42. Other manuscripts: Par. gr. 2406, fo. 64v, Scorialensis II. $\Psi$. 17, fo. 55v, Par. gr. 2425, fo. 220r-221v and Par. gr. suppl. 38, eds H. D. Curtis and F. E. Robbins, 'An Ephemeris of 467 A.D', Publications of the Observatory of the University of Michigan (1935), vol. 6, no. 9, pp. 77-100. This treatise is cited in an almanac for the year 1353: see R. Mercier, $A n$ Almanac for Trebizond for the year 1336 (Louvain la Neuve, 1994), p. 159.

${ }^{6}$ I cite from Par. gr. 2406, fo. 65r. Similar statements can often be found in Byzantine astrological manuscripts, where the principle of hairesis applies to the synaphe of the Moon to all the planets, cf. e.g. Parisinus gr. 2491 (CCAG 8/4 no.

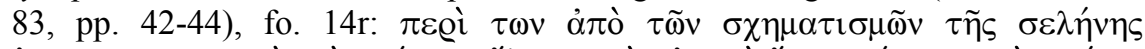

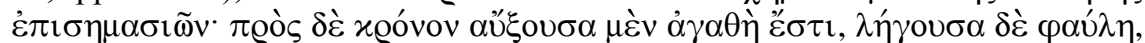

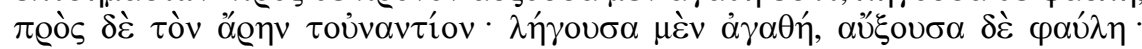

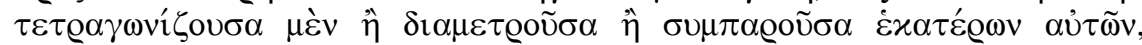

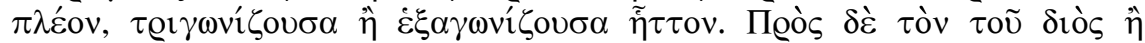

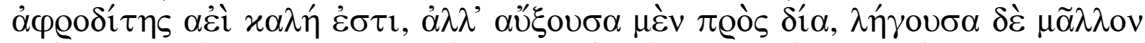

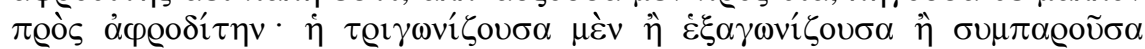

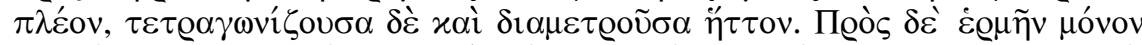

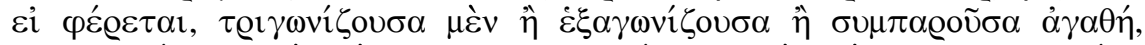

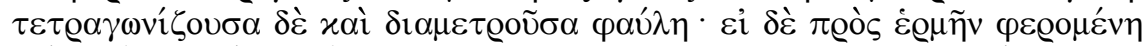

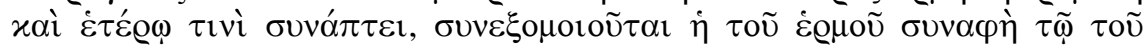
$\dot{\alpha} \sigma \tau \varepsilon^{\prime} \varrho \circ \varsigma \sigma \chi \eta \mu \alpha \tau \imath \sigma \mu \widetilde{\omega}$. Furthermore, a physical explanation of these aspects of

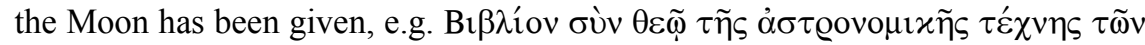

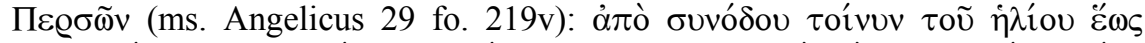

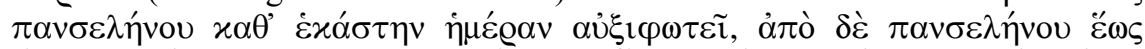

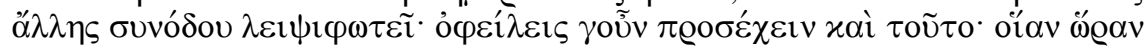

Culture and Cosmos 
This aphorism is widely attested in astrological literature. Sarapio of Alexandria says that if the Moon looks at Mars when it is waxing, or Saturn when it is waning, from quartile or opposition, especially when it is in a cardine, it produces loss and misfortune ${ }^{7}$. The reasoning behind this sentence (and many others like it) depends on the principle of

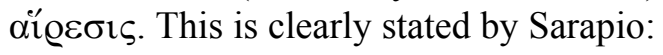

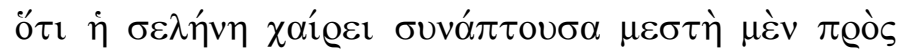

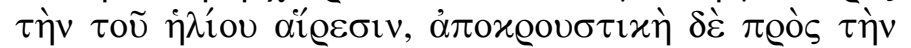
$\dot{\varepsilon} \alpha \nu \tau \tilde{\eta} \varsigma \alpha i \varrho \varepsilon \sigma \mathrm{e}$.

The Moon rejoices when, increasing in light, it applies to the sect (hairesis) of the Sun and, decreasing in light, applies to its own sect. ${ }^{8}$

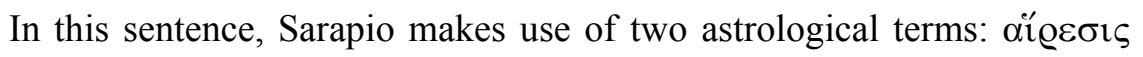
and $\chi \alpha$ ígeıv (to rejoice). We return therefore to the starting point of our discourse. When Ptolemy (Tetr. I, 7) explains the principle of the

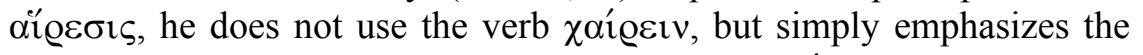
concept of suitable relation, symmetria $\left(\sigma \cup \mu \mu \varepsilon \tau \mathrm{Q}^{\prime} \alpha\right)$. It is the Greek anonymous commentator who, in expounding this notion of $\sigma \cup \mu \mu \varepsilon \tau \mathrm{Q}^{\prime} \alpha$, mentions chara ( $\chi \alpha \varrho \alpha ́$, joy):

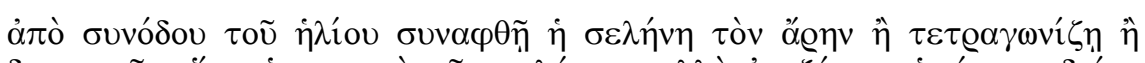

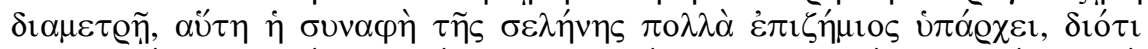

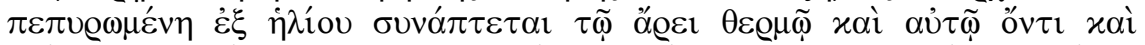

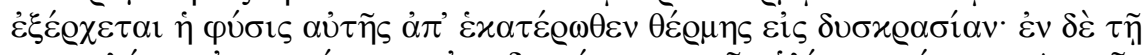

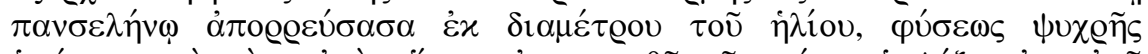

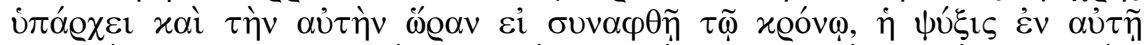

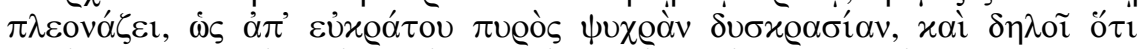

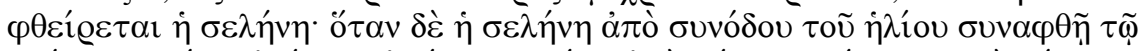

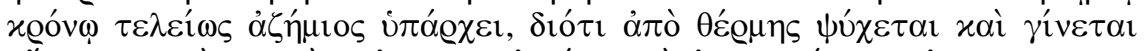

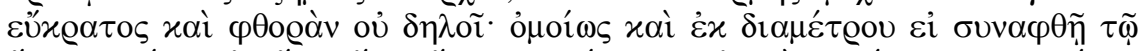

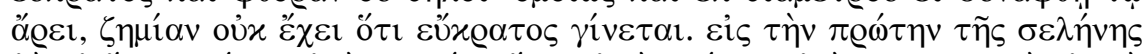

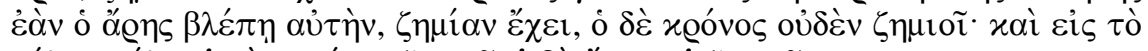

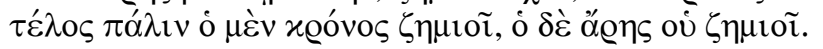

${ }^{7} C C A G$ 8/4, p. 229.33.

${ }^{8} C C A G$ 8/4, p. 229.11.

Culture and Cosmos 


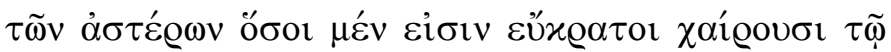

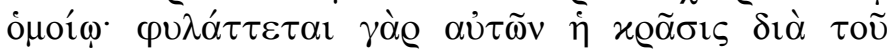

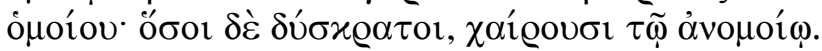

The well-tempered stars rejoice in what is like them, because they maintain their complexion through what is like them; but the stars of bad temperament rejoice in what is dissimilar to them. ${ }^{9}$

This interpretation is correct in the Ptolemaic sense; $\chi \alpha$ ígeıv is a hapax in

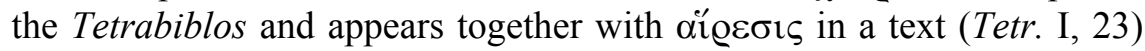

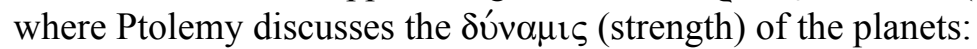

They say they rejoice ( $\chi \alpha$ ígeiv) when, even though the containing signs have no familiarity with the stars themselves, nevertheless they have it with the stars of the

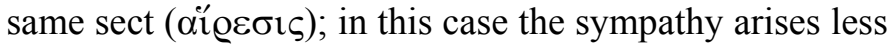
directly. They share, however, in the similarity in the same way; just as, on the contrary, when they are found in alien regions belonging to the opposite sect, a great part of their proper power is paralysed, because the temperament which arises from the dissimilarity of the signs produces a different and adulterated nature. ${ }^{10}$

To understand the concept of $\alpha i \varrho \varepsilon \sigma 1 \varsigma$ and its connection with $\chi \alpha \varrho \alpha$, let us examine briefly the first chapters of the first book of the Tetrabiblos, where Ptolemy deals with the natures of the planets. In I, 4

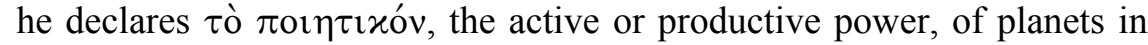
physical terms according to their primary qualities. In I, 5 he distinguishes the planets as benefic and malefic on the basis of their productive quality ( $\pi$ oı $\eta \tau \imath x o ́ v)$; Saturn and Mars produce excessive coldness and excessive dryness and are bad tempered. In I, 6 he makes a distinction between masculine and feminine planets based on the principle of the moist quality prevailing in them. Finally, in I, 7 he explains what the aigecis of planets is, but he does not mention the

${ }^{9}$ In Claudii Ptolemcei quadripartitum enarrator ignoti nominis, quem tamen Proclum fuisse quidam existimant (Basel, 1554), p. 23.

${ }^{10}$ Robbins' translation (Ptolemy, Tetrabiblos, tr. F.E. Robbins (Cambridge, MA, 1940, p. 113). 


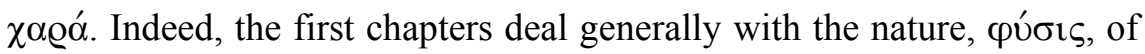
planets as a whole, while the $\chi \alpha \varrho \alpha$ is related to the different kinds of

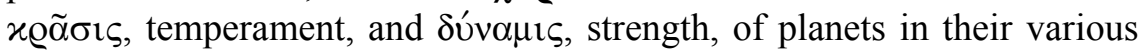
positions and configurations. As to their positions, the masculine and feminine places, both in the zodiac and in the diurnal motion, must be noted; as to their configurations, their morning or evening rising and setting. Ptolemy does not mention these conditions, but they are clearly pointed out by the Greek anonymous commentator:

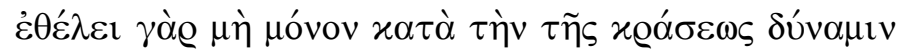

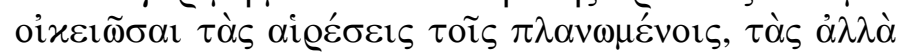

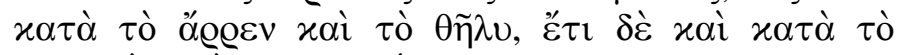

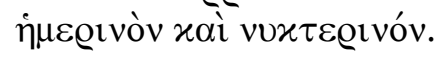

Vult nam non solum secundum complexionis potestatem factiones planetis assimilare, sed etiam secundum masculinitatem et femininitatem atque etiam secundum diurnum et nocturnum. ${ }^{11}$

For he wishes to affiliate the sects to the planets not only according to the power of the temperament, but also according to masculine and feminine, and even to day and night.

The whole matter has been explained, in a masterful manner, by Theophilus of Edessa:

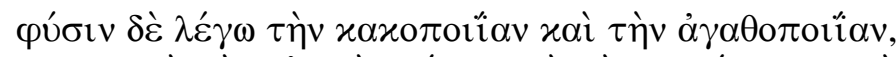

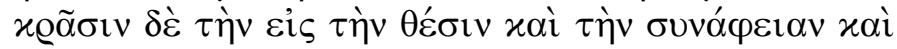

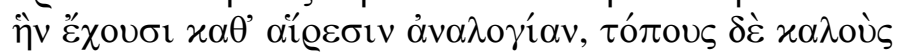

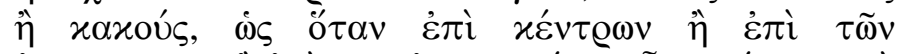

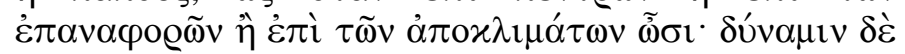

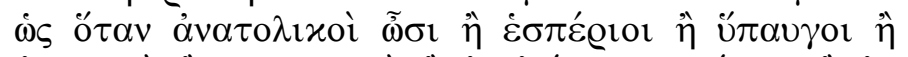

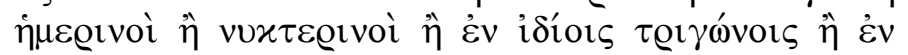

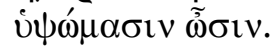

By nature, phusis, I mean the beneficent and maleficent quality; by temperament, krasis, what results from their

\footnotetext{
${ }^{11}$ My citation is from ms. Complutensis, Villamil. n. 27, fo. 15 r, which presents a more accurate text. The Latin version is from ms. Complutensis 117Z34, fo. $19 v$.
} 
position and application and their relation with respect to ai $\varrho \varepsilon \sigma 1 \zeta ;$ and as to the places, good or bad, I mean the angles, the succedents or the cadent places; by strength,

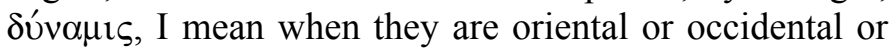
combust, or diurnal or nocturnal, or in their own trigons [triplicities] or exaltations. ${ }^{12}$

In the first chapters of the Tetrabiblos, Ptolemy gives an account of the

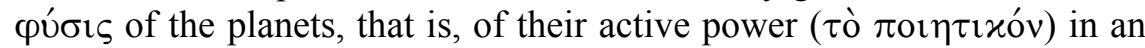
absolute sense, and in the seventh chapter he describes this same active power in a relative sense, namely compared to an ideal temperament. The hairesis of a planet is a symmetria, a good proportion, that brings the planet to a kind of $\mu \varepsilon \sigma o ́ \tau \eta s$ (happy medium) of its active power. So hairesis is not a part of nature, but must be considered for judging the

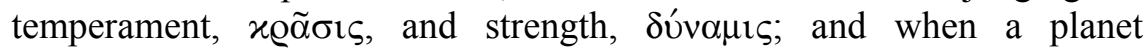
maintains a good proportion with respect both to temperament and strength, they say that it is rejoicing, $\chi \alpha$ íget. Julian of Laodicea expresses this concept well in the following sentence:

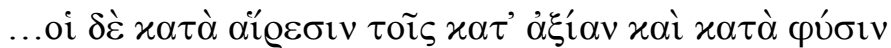

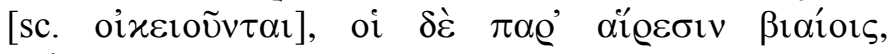
$\dot{\alpha} \delta \dot{\prime} x 015 . .$.

...the planets consonant with their hairesis signify what happens befittingly and according to nature, but those non consonant signify violent events and injustice... ${ }^{13}$

Furthermore, because accordance with hairesis produces a temperament, astrologers judge sympathy and identity from it: if Mars

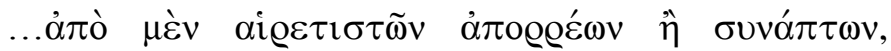

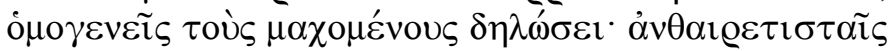

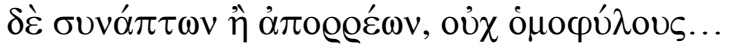

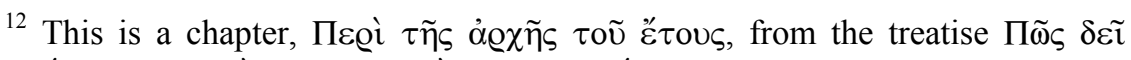

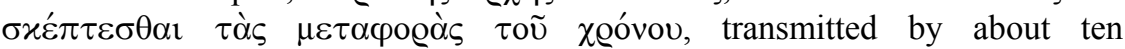
manuscripts. My text is slightly different from the fragment published, without the name of Theophilus, by S. Weinstock in CCAG 9/1, pp. 176-79.
}

${ }^{13}$ CCAG 5/1 p. 190.11-12. 
236 From Greek hairesis to Arabic hayyiz

...separates from or applies to planets of the same hairesis, this shows that the fighters are of the same tribe; but if it separates from or applies to planets of the opposite hairesis, they are not of the same race.... ${ }^{14}$

Finally, accordance with hairesis tempers the destructive effect of the maleficent planets. As a general rule, Dorotheus says:

mā yaḍurru zuhal bi-man walada nahārā wa-'l-mirrīkh bi-man walada laylā

Saturn does not harm one who is born by day and Mars one who is born by night. ${ }^{15}$

In the treatment of hairesis and chara there are no substantial differences in Greek astrology. Nevertheless, it is possible to discern, among the few extant statements, a difference between strict and welldefined comments and others more open to interpretation. To the first group belong those of Rhetorius, Sarapio of Alexandria ${ }^{16}$ and Vettius Valens; ${ }^{17}$ to the second, those of Antiochus, ${ }^{18}$ Paulus of Alexandria, ${ }^{19}$ and

\footnotetext{
${ }^{14}$ Julian of Laodicea, $C C A G$ 5/1, p. 183.20-22.

${ }^{15}$ Carmen astrologicum I, 6. Pingree's translation is not accurate, cf. ibid. p. 165.

${ }^{16}$ Sarapio Al., CCAG 8/4, p. 231.16-22: 'Saturn, Jupiter and Mars rejoice when they are morning stars and in mutual aspect, but the Moon and Venus when they are following the Sun and are evening stars. Besides, Saturn, Jupiter and Mars rejoice when they are situated in the oriental quadrants of the zodiac, but the Moon and Venus in the others. Also, the diurnal planets rejoice by day above the earth and the nocturnal ones below; and at night the diurnal planets rejoice below

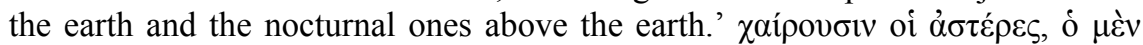

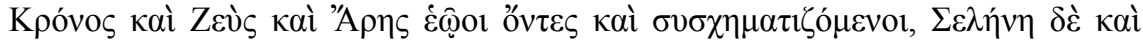

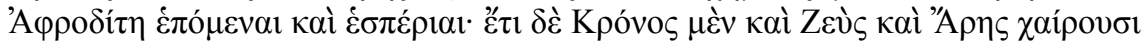

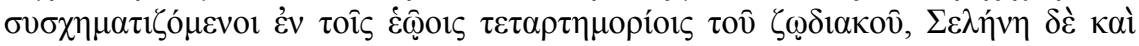

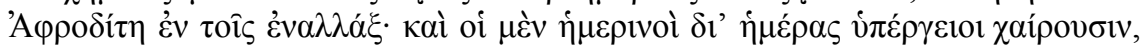

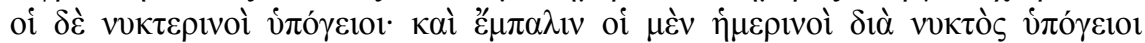

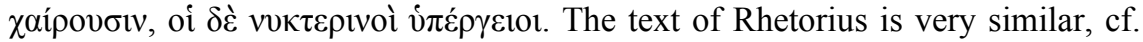
$C C A G$ I, p. 159.20 (a better version is in Par.gr.2501, fo. 193r).
}

${ }^{17}$ Anthology, III, 5; p. 133.31-134.7 Pingree: 'It is also necessary to consider the hairesis of the stars, for the Sun, Jupiter and Saturn rejoice when they are above the earth by day and below at night. The Moon, Mars and Venus rejoice when 
Firmicus. ${ }^{20}$ In fact, these comments are not in opposition. On the

they are above the earth at night and below by day; Mercury goes with the hairesis of the ruler of his terms. Hence, for those who are born by day, if someone should be found to have Jupiter, the Sun and Saturn well aspected above the earth, it will be better than having them beneath the earth. Similarly also for the nocturnal planets, if someone should have them above the earth at

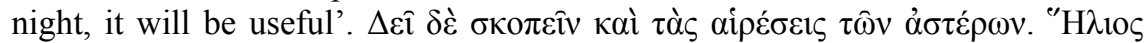

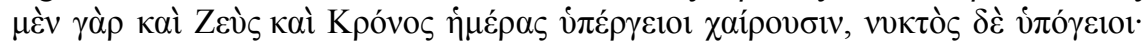

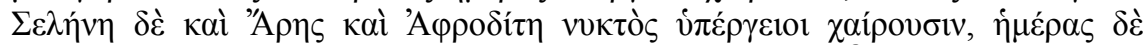

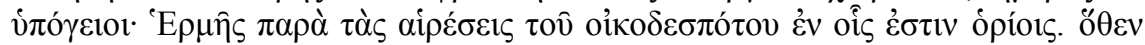

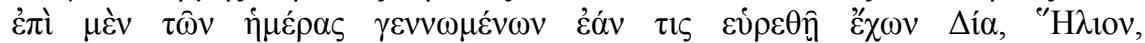

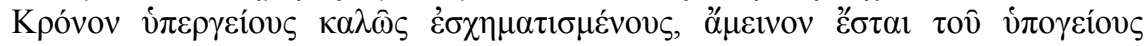

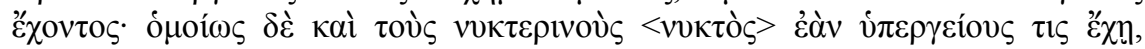

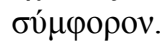

${ }^{18} C C A G$ 8/3, p. 112.8-13: 'Of the five planets, Saturn and Jupiter, when they are morning stars, share the hairesis of the Sun and are called diurnal: they rejoice during the day by being operational in diurnal domiciles and terms. Mars and Venus are called nocturnal and they share the hairesis of the Moon. Mercury is common and it assimilates to the star with which it is in relationship'. $\tau \hat{\omega} v \varepsilon^{\prime}$

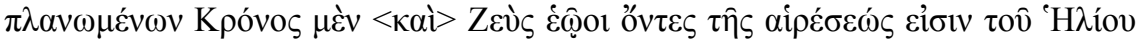

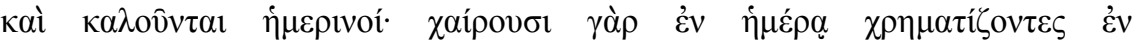

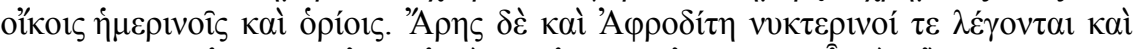

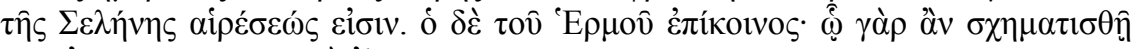

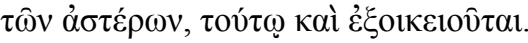

${ }^{19}$ Cf. ch. 6, p. 18.16-19.4 Boer. 'The Sun is in possession of the day, the

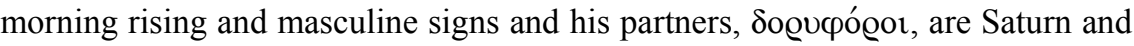
Jupiter. The Moon is in possession of the night, the evening rising and the

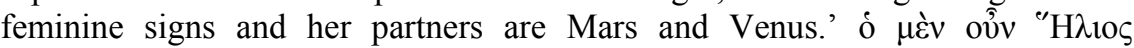

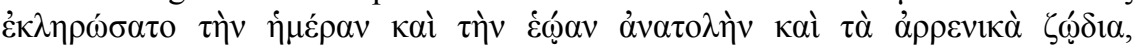

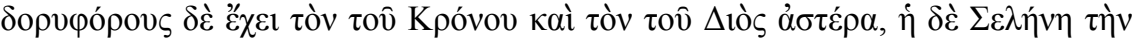

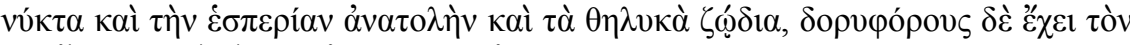

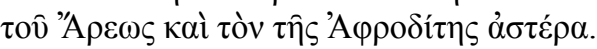

${ }^{20}$ Mathesis, II, 7.2, Kroll, Skutsch I, p. 49: De stellarum conditione. Per diem gaudent Sol Iuppiter Saturnus; conditionem itaque Solis secuntur Iuppiter et Saturnus; ideo in diurnis genituris in oportunis locis positi maiorem vim habent, ac ut plurimum bonam fortunam, fœlicitatemque decernunt. Per noctem autem gaudent Luna, Mars ac Venus; conditionem itaque Lunæ sequuntur Mars et Venus, nam Mercurius, quoniam ad utranque naturam se accommodat, ideo modo diurnus est, modo nocturnus, sed orientalis diurnus est, occidentalis vero nocturnus, hic fortior quam illis, permixtis tamen stellis inter utrunque

Culture and Cosmos 
contrary, they show a common principle: the planets of each hairesis

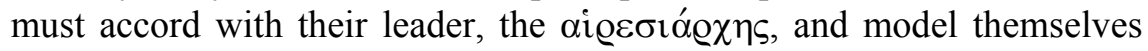
on its nature and behaviour. Thus, diurnal planets rejoice during the day, in masculine signs and in masculine quadrants, and in their morning rising (both oriental to the Sun and visible); nocturnal ones, during the night, in the feminine signs and quadrants, and in their evening rising (i.e. occidental to the Sun and visible). Of all these conditions, the first in order and efficacy is the heliacal rising, because the first appearance of the planet, in the morning or in the evening, is the visible beginning of its synodic cycle and has always been considered as the most valid evidence of its strength. Theophilus of Edessa clearly expresses this concept when speaking of the strength of the phases of the planets:

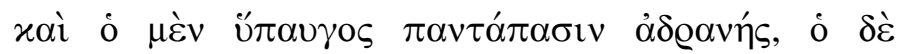

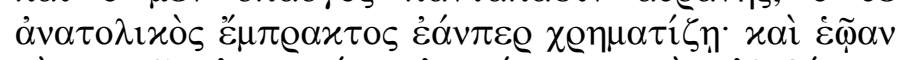

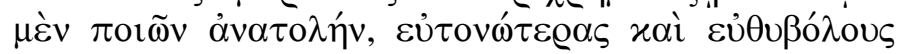

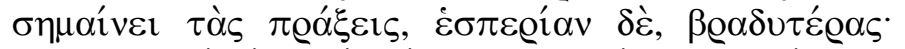

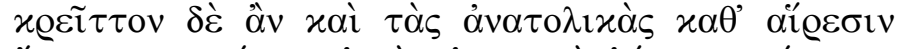

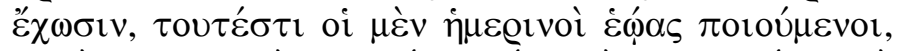

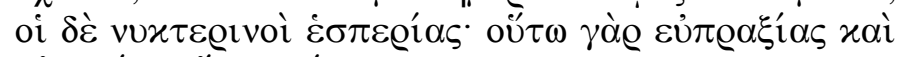

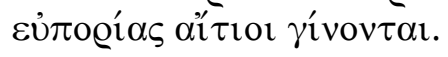

The combust planet is wholly impotent and the rising one is effective, if it occupies an operative place; and if it is making a morning rising it signifies vigorous actions, hitting the mark; but at its evening rising the actions are slower. And it is better if the rising is according to the hairesis, that is, when the diurnal planets make morning

concedens ('maiorem...concedens' only in Iulius Firmicus, Astronomicorum libri octo, ed. Pescennius Franciscus Niger [Venice, 1499]).

II, 20.11, Kroll and Skutsch I, p. 67: Quaere etiam, si diurna genitura est, quatenus stellæ, quæ per diem gaudent, positæ sint et quatenus quæ nocturnis; si enim stellæ, quæ per diem gaudent, in diurna genitura principales possederint locos et in primis cardinibus fuerint inventæ, maxima felicitatis incrementa decernunt. Si vero stellæ, quas per noctem gaudere diximus, in diurna genitura principalia loca vel primos genituræ possederint cardines, infinita infortunia continuatis calamitatibus indicunt. 
risings and the nocturnal ones evening risings: thus they

become the cause of success and abundance. ${ }^{2}$

Moreover, the phases of the planets, not as a whole, but according to the hairesis, form the basis for the ogupogía, attendance, because in the doryphoria the planets are required to be in accordance with the hairesis:

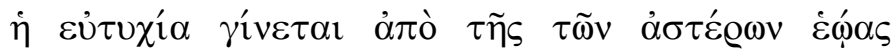

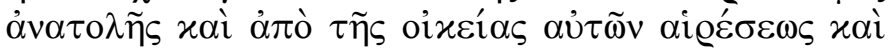

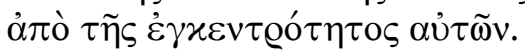

The success comes from the morning rising of the stars and from their suitable hairesis and from their positions in the cardinal points. ${ }^{22}$

One of the later Greek texts that gives an account of hairesis is the scholia of Demophilus, an astrologer of the 10th century, at the end of the Introduction to the Tetrabiblos ascribed to Porphyry. In these scholia, Arabic elements seem to be absent. Nevertheless, in the scholia numbered by Weinstock 53 and 54, he presents two schemas of hairesis, each of them doubled, according to the position of the planet either in reference to the Sun or to its motion along the zodiac. Furthermore, Demophilus does not take into consideration the distinction between diurnal and nocturnal planets, but only between superior and inferior ones. Furthermore, at the beginning of scholion no. 53, Demophilus makes use of a technical term that does not belong to Greek astrological literature:

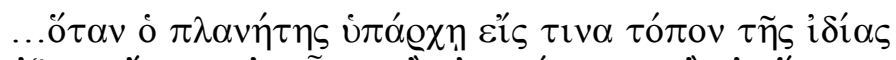

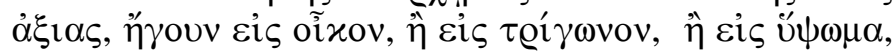

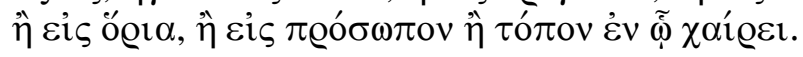

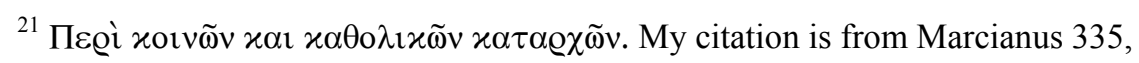
fo. $88 \mathrm{v}$.

${ }^{22}$ Greek version of the commentary of the pseudo-Ptolemaic Centiloquium of Ahmad ibn Yūsuf ibn al-Dāya, kalima 29. The Arabic text has tashrīq instead of

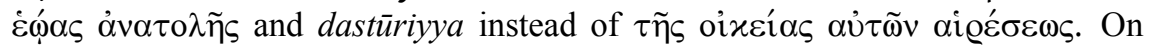
these terms, see al-Bīrūnī, The Book of Instruction in the Elements of the Art of Astrology, ed. R. Wright, (London, 1934), pp. 296ff.; G. Bezza, Commento al primo libro della Tetrabiblos di Claudio Tolemeo (Milan, 1991), pp. 132-37.
} 
240 From Greek hairesis to Arabic hayyiz

...when a planet is in a place of one of its dignities, that is to say, in its domicile or triplicity or exaltation or term or decan or in a place which is its joy. ${ }^{23}$

The term $\dot{\alpha} \xi i \alpha$ (axia, dignity) translates the Arabic hazz, and for this reason we can presume that the scholia of Demophilus depends on an original Arabic text. No term exactly equivalent to hazz can be found in

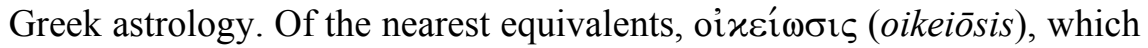
Ptolemy favours, has a very broad sense of connection of things, with a

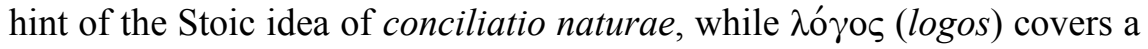
wider semantic field. In fact, Demophilus, who lived in the late 10th century, translated word for word a text of Sahl ibn Bishr (first half of 9th century) about the conditions of the strength of the planets, and this text was frequently quoted in medieval astrology. ${ }^{24} \mathrm{Hazz}$ has two meanings: 'fortune, good fortune', and 'share, portion'. The latter is the meaning of hazz as an astrological technical term. When the astrologers say that the planets have, in the zodiacal signs, a domicile, exaltation, triplicity, term

${ }^{23}$ CCAG 5/4, p. 226.24-27.

${ }^{24}$ See in Appendix A the parallel texts of Demophilus, Sahl and Andalone di Nigro. Viktor Stegemann was the first to show the dependence of many scholia of Demophilus on the text of Sahl ibn Bishr: see Doroteo von Sidon und das sogenannte Introductorium des Sahl ibn Bišr (Prague, 1942), pp. 83-87. A Byzantine translation of the text of Sahl ibn Bishr has been published in $C C A G$ $5 / 3$, p. 109. The topic of the fortitudines planetarum usually consists of eleven clauses and there are two distinct forms: the tradition handed down by Abū Ma'shar (Liber introductorii maioris ad scientiam judiciorum astrorum, VII, 6, ed. R. Lemay, [9 vols, Naples, 1995] [hereafter Greater Introduction], III, p. 546) and al-Qabīṣi (The Introduction to Astrology, eds Ch. Burnett, K. Yamamoto, M. Yano, [London - Turin, 2004], III, 25-26, p. 100) and that transmitted by Māshā'allāh (cf. Incipit liber Messahala de 14. proprietatibus stellarum que videlicet generationi et corruptioni omnium rerum deserviunt, ms. Bodl. Oxford Digby 47, fo. 88v-89r) and by Sahl ibn Bishr (Incipit introductorium de principijs iudiciorum Zahelis Ysmaelite, apud Liber quadripartiti Ptholemei [Venice, 1493] [hereafter Liber quadripartiti Ptholemei], fo. 125ab). The latter is the best attested, sometimes with reference to Sahl, cf. Thomas Rocha, Incipit compilatio quedam terminorum astronomie (Montpellier, 1501), S. b4r-v: 'Confortatio planetarum seu vigoris crementum fit propter locum in quo est, quia locus ille iuvat planetam et secundum Algazel fit multis modis...'.

Culture and Cosmos 
or decan, they say, as a general rule, that the planets have one hazz or more huzu $z$ in the signs. ${ }^{25}$ Therefore, the technical meaning of hazz is more restrictive than the Ptolemaic $\lambda$ ó $\gamma \circ$, although it is very similar. AlBīrūnī gives nașib as a synonym for hazz, to signify that a planet has a 'share' in its sign; but, if that is not the case, it is said to be gharïb, odd, a stranger. ${ }^{26}$ Later on, medieval astrology acquired these terms, and hazz becames dignitas, gharīb and ighrāb, peregrinus and peregrinitas. ${ }^{27}$ Even though dignitas does not reproduce the exact meaning of hazz, Latin medieval astrologers were aware of its interpretative context.

As a general rule, a distinction was made between dignitates essentiales and accidentales, the former being related to motion along the zodiac, that is, the zodiacal signs, the latter to diurnal motion, that is, the houses. This distinction clearly reveals an indebtedness of Latin medieval astrology to the Arabs. The dignitates essentiales originate from the Arabic al-huzūz al-dhātiyya or huzūz bi-l-țab' ('essential dignities' or 'dignities according to nature'), ${ }^{28}$ the dignitates accidentales from alhuzūzal-'ardiyya or huzūzọ bi-l-ard ('accidental dignities'). ${ }^{29}$

${ }^{25}$ Cf. al-Qabīṣī, The Introduction to Astrology, I, 13, p. 22, line 49.

${ }^{26}$ Al-Bīrūnī, The Book of Instruction, p. 306, § 493.

${ }^{27}$ In his translation of the Liber introductorii maioris of Abū Ma'shar, John of Seville always renders hazz with dignitas. Cf. G. Vitali, Lexicon mathematicum astronomicum geometricum (ristampa anastatica dell'edizione parigina del 1668), ed. G. Bezza, (La Spezia, 2003), p. 406 (370): 'Peregrinus apud astronomos dicitur planeta repertus in loco, ubi nullam habet dignitatem, ex quinque essentialibus, domicilio nempe, exaltatione, trigono, terminis et facie, ut Sol in Virgine, Luna in Geminis, etc.'.

${ }^{28}$ Al-Qabīṣi has both expressions, cf. The Introduction to Astrology, I, 13: I, 22; I, 70; III, 31. Cf. Leonardo Qualea, Compendium clari viri Leonardi Qualea quod Astronomiam medicinalem nuncupari voluit, ex multis Syrorum, Indorum, Arabum, Persarum, Egyptiorum, Grecorum et Latinorum voluminibus compilatum in facilitatem medicorum et commoditatem infirmorum, ms. Paris, Bibliothèque nationale de France, lat. 10264, fo. 71r: 'Quasdam potestates naturales, quasdam vero actuales habent singuli planete in signis (...) Naturales igitur potestates sunt septem et actuales tres. Naturales potestates sunt: domus, exaltatio, triplicitas, terminus, gaudium, facies et dignitas; actuales vero sunt virtus, dies et hora'.

${ }^{29}$ When reference is made to the strength that planets acquire thanks to their huzūuz, astrologers speak of quwwa, potestas, like Qualea (see note 28 above).

Culture and Cosmos 
However, because hazz also means good fortune, felicitas vel proprie portio boni cuiusdam, ${ }^{30}$ when a planet is in one of its huzūz, it always indicates something good. But, if one of the principal places of a man's nativity is in the huzūz of a maleficent planet, it cannot indicate evil.

Si fuerit Mars dominus horoscopi, cum planete non infortunent dignitates suas (wa laysa yanhasu al-kawākib huzūz) quin dispergat et impediat quicquid est in secunda ... salvabit quod est ascendentis. ${ }^{31}$

If Mars is the lord of the ascendant, because the planets do not harm his dignities, although he will squander and obstruct whatever is in the second [place]...he will preserve what belongs to the ascendant.

Hazz is frequently used in the sense of share and therefore it is not different from the technical astrological meaning of the Greek $\lambda$ ó $\gamma_{0}$; see,

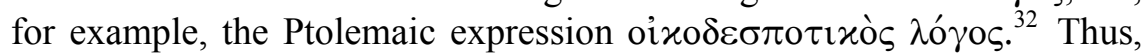
because the first significance of hazz is 'good fortune', it indicates having a share in some good. When the astrologers speak of huzūz bi-l-tab', this

Cf. al-Qabīṣī, The Introduction to Astrology, I, 22; Kūshyār ibn Labbān, Introduction to Astrology, ed. and trans. M. Yano, (Tokyo, 1997), p. 55: 'The powers of the planets $<$ of which there are three kinds $>$ : $<1>$ the essential, $<2>$ the accidental, and $<3>$ the beneficial'; cf. the pseudo-Ahmad al-Farsī (Angelicus 29, fo. 185r, cap.164; cfr. Palatinus gr. 312, fo. 92v cap.23 and

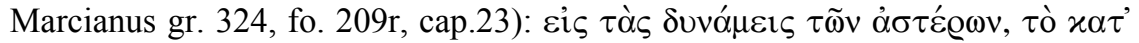

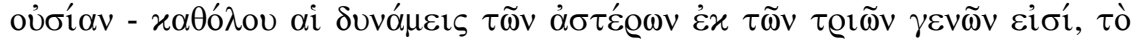

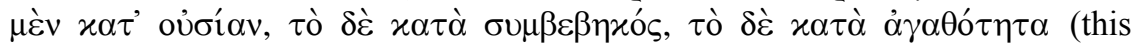
anonymous compilation depends greatly on the treatise of Kūshyār ibn Labbān).

${ }^{30}$ G. W. Freytag, Lexicon Arabico-latinum (Beirut, 1975), I, 397 b.

${ }^{31}$ Aḥmad ibn Yūsuf ibn al-Dāya, Kitāb al-thamara, kalima 85 (in substantia intronizanti), apud Liber quadripartiti Ptholemei, fo. 115ra. On the other hand, if the malefic is in the opposite condition, it will destroy the native's body, cf. ibid., fo. 114ra, kalima 75: 'Cum Mars coniunctus fuerit cum domino ascendentis corporaliter in Leone et non fuerit Marti in ascendente aliqua dignitas (wa-lam yakūn li'l-mirrīkh ḥazz fì 'l-țāli') ... natus ille cremabitur'.

${ }^{32}$ Apotelesmatika III, 3, eds Boll Boer, p. 111.12.

Culture and Cosmos 
good preexists potentially, but it exists in actuality in the huzūz bi-l'ard . This difference was well understood by Qualea in his Aristotelian distinction between potestates naturales and actuales. ${ }^{33}$ And because this good is something in nature, an essence, the astrologers provided some metaphorical meanings for these goods. ${ }^{34}$ Astrologers often represent by

${ }^{33}$ See note 28 above. This meaning is well understood by M. Gloton, who translates hažz by prédisposition, cfr. 'Alī b. Muhammad al-Jurjānī, Kitāb alTa'rifāt (Teheran, 1994), p. 184.

${ }^{34}$ Cf. al-Qabīṣ̂̄, The Introduction to Astrology, I, 23, p. 32, line 145; Iudicia Alkindi, apud al-Qabīṣ̂̄, p. 392; Kūshyār ibn Labbān, Introduction, I, 19.2, p. 55; Incipit liber Messahala de 14. proprietatibus, fo. 92r: 'Nam stella quelibet in propria domo et fortitudine vigens homini in domo propria et sue professioni viriliter insistenti comparatur. Nam in regno suo cuilibet regnanti vel regi similis est. In ternario quoque quasi qui inter custodes et defensores et coadiutores moratur et huius formam retinet. Rursus stella in termino suo homini qui in patria et cognatione versatur similis est. In facie existens quasi artifex dum formas et ymaginum figuras insculpit reputatur'; 'Alī ibn Riḍ̂ān, apud Liber quadripartiti Ptholemei, fo. 23a: 'potentia planete in domo sua similis est potentie hominis in sua domo, qui ibit quocumque voluerit et faciet quod sibi placebit. Et potentia planete in triplicitate sua similis est potentie hominis inter vassallos et auxiliatores suos. Et potentia planete in exaltatione sua similis est potentie hominis in regno suo. Et potentia planete in suo termino similis est potentie hominis in villa sua. Et potentia planete in sua facie similis est potentie hominis in magisterio suo'; pseudo-Ahmad al-Farsī (Angelicus 29, fo. 185r, cap.164; cfr. Palatinus gr. 312, fo. 92v cap. 23 and Marcianus gr. 324, fo. 209r,

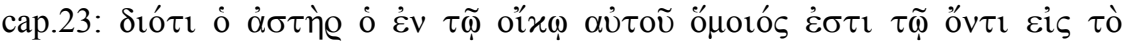

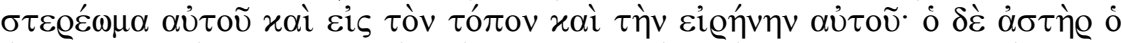

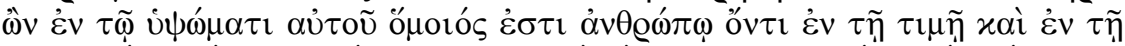

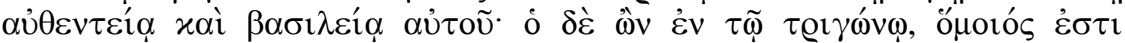

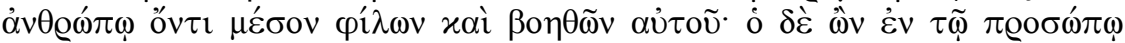

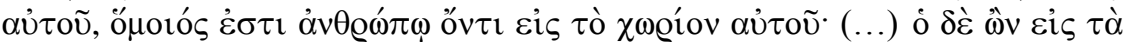

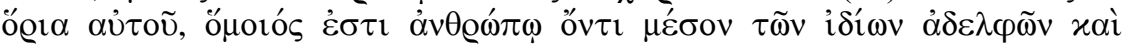

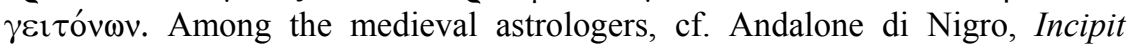
introductorium valde necessarium ad iudicia astrologie editum a domino andolo de nigro de janua in arte astrologie peritissimo, ms. Paris, Bibliothèque nationale de France, lat. 7272, fo. 106rv: 'Quidam autem de hac re dederunt comparationem dicentes quod planeta cum in domo sua fuerit simils est viro in domo atque sua dominatione. Et cum fuerit in termino suo est sicut vir inter parentes suos cognatos atque gentes. Et cum fuerit in triplicitate sua et est sicut vir in suo honore et in ter auxiliatores atque ministros suos. Et cum fuerit in facie sua est sicut vir in suo magisterio. Hec sunt universe potestates planetarum essentiales in signis'.

Culture and Cosmos 
metaphorical images what the planets signify in the various states of their motions, ${ }^{35}$ but the authors mentioned above (see note 34 ) add some other metaphorical images, related to the huzūz bi-l-ard: Kūshyār ibn Labbān

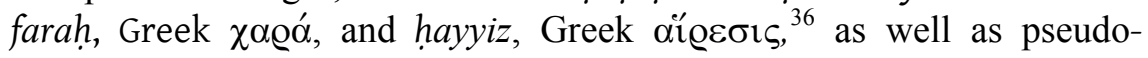
Aḥmad al-Farsī, who usually follows Kūshyār ibn Labbān, where hayyiz

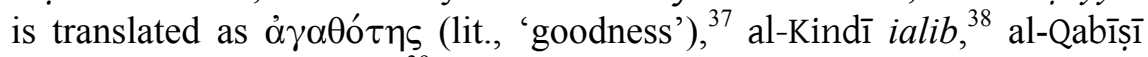
halb and hayyiz together, ${ }^{39}$ Māshā'allāh ḥayyiz, translated into Latin as habitudo. ${ }^{40}$

The dignitates accidentales are obviously more numerous than the dignitates essentiales, because they indicate various states at one or more moments in time. In Arabic astrology these states are named hāalāt or

${ }^{35}$ See, for example, Abrahe Avenaris Iudei astrologi peritissimi in re iudiciali opera: ab excellentissimo philosopho Petro de Abano post accuratam castigationem in latinum traductum ( Venice, 1507), fo. 27r-28v (Principium sapientiae); Libri mysteriorum Apomasaris, II, §167ff.

${ }^{36}$ Kūshyār ibn Labbān, Introduction, I, 19.2, p. 55: 'When it (the planet) is in its "joy" (farah) it is like a man in his recreation ground and gaiety; when it is in its "domain" (hayyiz), it is like a man among his acquaintances and friends'.

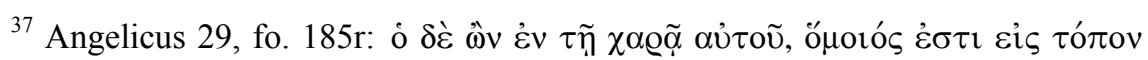

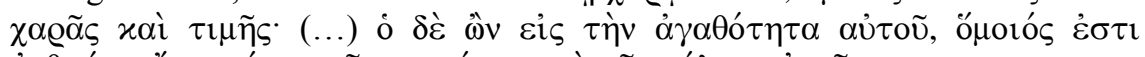

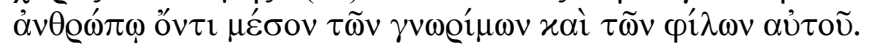

${ }^{38}$ Iudicia Alkindi, apud al-Qabīṣī, The Introduction to Astrology, p. 392: 'In ialib viget velud vir lucrans fortunaque pollens'. Cf. Guido Bonatti, Decem continens tractatus de astronomia, (Augsburg, 1491), ccD3,2r: 'Unde cum planeta fuerit significator alicuius rei et fuerit in sua similitudine melius et perfectius, perficiet rem quam significaverit quam cum non fuerit in sua similitudine. Et est aym quedam fortitudo et tunc erit planeta aliquantulum fortior quam cum non est in sua aym, sicuti est qui est in statu in quo lucretur et satisfacit quodammodo sue intentioni et perficit et fortuna videtur ei favere'.

39 Al-Qabīṣī, The Introduction to Astrology, I, 78, p. 61: 'Its power is like the power of a man in the place of his benefits, his gain, and his good fortune'.

${ }^{40}$ Incipit liber Messahala de 14. proprietatibus, fo. 92r: 'Quod si sue habitudinis locum obtineat, ut diurna de die et econtra quasi qui lucri et prosperitatis sorte splendescit'; cf. John Danko of Saxony, Scriptum super Alchabitium... (Venice, 1521), fo. 48a: 'Et erit tunc fortitudo sua sicut fortitudo viri in loco sui profectus et lucri atque fortune'.

Culture and Cosmos 
awhāl (sing. hâal). Hiāl means a temporary condition, which is opposed to malaka, the permanent one. These are their meanings as philosophical terms: ḩăl translates the Aristotelian term $\delta 1 \alpha \dot{\theta} \theta \varepsilon \sigma \iota \varsigma$ (diathesis, 'active condition'), which is opposed to ع̈ $\xi 1 \varsigma$ (hexis, 'state'). Abū Ma'shar, in the in the Kitāb al-mukhtașar, describes 25 hăāāt of the planets, the first of them being the hayyiz. ${ }^{41}$ Kunitzsch $^{42}$ and Pingree ${ }^{43}$ supposed that the technical terms of these hālāt pre-existed in the late Antique Greek astrological treatises. It is, however, hard to agree with this. Many of these terms do not have a corresponding Greek word and very few of them are attested in the Greek astrological treatises. It is, however, true that Ptolemy's commentators, from Ibn Riḍwān to Cardanus and Naibod, considered the doctrine of the hālāt as an implicit development of the last two chapters of the first book of the Tetrabiblos, and virtually contained in it. ${ }^{44}$ But Arabic astrology profoundly extended the technical lexicon

${ }^{41} \mathrm{Cf} . \mathrm{Abu}$ Ma'shar, The Abbreviation of the Introduction to Astrology, ed. and trans. Ch. Burnett, K. Yamamoto, M. Yano, (Leiden, New York and Cologne, 1994), p. 40. Sahl ibn Bishr (Kitāb al-aḥkām 'alā al-niṣba al-falakiyya, cf. M. Ullmann, Die Natur- und Geheimwissenschaften im Islam [Leiden, 1972], pp. 309ff. Stegemann, Doroteo von Sidon, p. 37) does not use the term hāal, but wajh, in Latin translation modus, and most of the Latin astrologers follow him: Andalone di Nigro, Introductorium, fo. 164r: 'de effectu et detrimento planetarum in modis 16.'; Magister Romanus, Tractatus de xvi impedimentis in astronomia, ms. München, Bayerische Staatsbibliothek, Clm 25005, fo. 50v: 'Scito quod omne quod stelle significant sc. an res fiant et perficiant aut quod prohibent quod non fiant nec perficiuntur et que sunt et destruuntur postquam sint perfecte, sit 16. modis'; Bonatti, Decem tractatus de astronomia, S. f7ra, G1ra ('16. modi'); John Danko of Saxony, Scriptum super Alchabitium, fo. 54a ('esse, modi').

42 P. Kunitzsch, Mittelalterliche astronomisch-astrologische Glossare mit arabischen Fachausdrücken (Munich, 1977), p. 25, n. 43.

${ }^{43}$ D. Pingree, From Astral Omens to Astrology. From Babylon to Bīkānēr (Rome, 1997), p. 71 .

${ }^{44}$ Cf. Ibn Riḍān, apud Liber quadripartiti Ptholemei (ca. xxii. In almugea, id est in visionem adinvicem facie ad faciem et in alchinara, id est splendore, et in his similibus) fo. 28va: 'Ptholemeus nominat in hoc loco status planetarum respectu unius ad alium et dicit quod planete gaudent et fortificantur cum habuerint participationem unius scilicet cum alio qui secum concordet concordia naturali vel accidentali, quamvis planeta non sit per se in signo convenienti sibi et econtra. (...) Hi vero status secundum quod multi sapientum dixerunt sunt

Culture and Cosmos 
246 From Greek hairesis to Arabic hayyiz

and often the same concept has a different name and a different meaning in Greek and Arabic astrology. That is the case for the Greek term

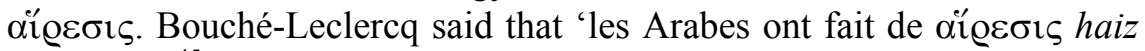
ou alahiz' ${ }^{45}$ but these terms are neither the transcription of the Greek word, nor the loan-translation used to render its meaning. ${ }^{46}$ The proper meaning of hayyiz is 'a container or receptacle of anything'. In philosophical terminology hayyiz is the 'spatial domain'47 and in Scholastic theology, 'ilm al-kalām, it is the imaginary portion of space occupied by a thing having an extent. Thus, hayyiz signifies the sphere of activity, the juste milieu. A star in its domain, fi hayyizihi, is well placed, as if it is in its proper natural place, al- hayyiz al-țabit ${ }^{-1}$. It is in a position to carry out an effect and signifies temperamentum et aptationem (al-itidal wa-l-saläh..$^{48}$ Moreover, because it occupies a hayyiz, it is named mutahayyiz: this word means 'associated, member of a society' and also 'a partisan'. In conclusion, although Arabic astrologers shaped the Greek

undecim modi completi, quoniam omnes alij status ad hos undecim referuntur, et habent unam ad quam referuntur radicem'. The Anonymus Cracoviensis repeats the undecim modos completos of Ibn Riḍān and remarks: 'multas habitudines planetarum posuit Albumazar et Alkabicius, tamen isti sunt de quibus Haly facit commemoracionem', Ad tabulam quadripartiti Ptholomei, ms. Laurentianus Ashburnham 202, fo. 29r.

${ }^{45}$ A. Bouché-Leclercq, L'astrologie grecque (Paris, 1899), p. 103, n. 2.

${ }^{46}$ See Kunitzsch, Mittelalterliche astronomisch-astrologische Glossare, p. 33: 'Ayz: arab. al- hayyiz, Lehnübersetzung zur Wiedergabe des ptolemäischen

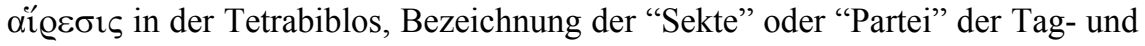
Nachtplaneten'.

${ }^{47}$ Cf. E. E. Calverley and J. W. Pollock, Nature, Man and God in Medieval Islam (Leiden, 2002), I, p. 400, n. 96: 'hayyiz is the criterion by which bodies are sensately distinguished from each other, spatial domain being a more general term than place, makān, and it is used to deal with the precise position, wad', in which one undefined thing may differ from another in reference. Thus, a thing would be "within its spatial domain", mutahayyiz, but would not be in a "place".

${ }^{48}$ Abū Ma'shar, Greater Introduction, ed. R. Lemay, versio latina Ioannis Hipsalensis, V, p. 276.134; Arabic text III, p. 522.74.

Culture and Cosmos 
notion of hairesis into a different form, we cannot find a substantial difference between the mutahayyiz and the equivalent Greek terms. ${ }^{49}$

On the other hand, medieval Latin astrologers not only made a transcription of the Arabic hayyiz, ${ }^{50}$ but also tried to find a Latin word which could represent the idea of this concept. ${ }^{51}$ Broadly speaking, the

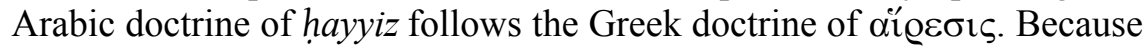
at the basis of these doctrines there is the principle of symmetria and good proportion, the term similitudo often can be found in Latin medieval literature as the equivalent of hayyiz. For example, Giorgio Anselmi, who wrote in the first half of the fifteenth century, says:

Arabes nominant hayç stelle dispositionem qui nos similitudinem. Exultat siquidem stella omnis cum locum sive in mundo sive in zodiaco nature sue similem sortita fuerit. Congaudent enim similibus similia, unde et que diurne videntur stelle super emisperium diurnum percurrentes luce gaudent. Que vero nocturne, nocturnum nocte; et que masculine sunt cum signa masculina tenuerint, que feminine cum feminina; et que calide

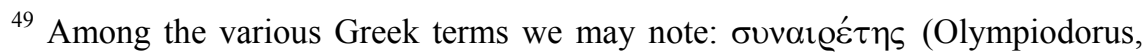
ed. Æ. Boer, pp. 6.9; 17.16; 39.15; Abramius, ed. Pingree, p. 206);

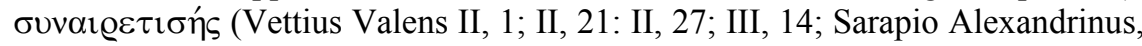

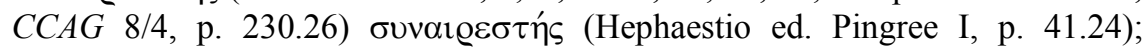

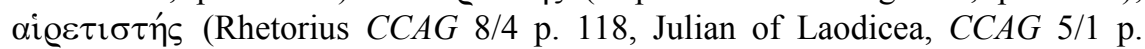

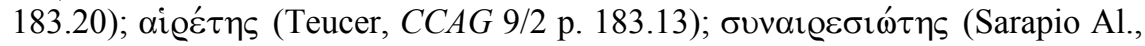

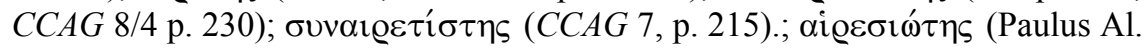
ed. Æ. Boer p. 94.4).

${ }^{50}$ A list of these terms can be found in Kunitzsch, Mittelalterliche astronomischastrologische Glossare, p. 33, n. 60: 'In lateinischen Texten erscheint (al-) hayyiz in mannigfaltigen Formen: alahiz, alaiz, alhais, Auz, ayz, haoç, Haijs, haiz, Hays, hayz (zu beachten ist, dass die nach unten gezogene Form des $\mathrm{z}$ am Wortende auch als Schluss $-m$ missverstanden werden konnte, so dass auch Formen auf $-m$ vorkommen!).'

${ }^{51}$ It is noteworthy that in Zebelenos, who largely depends on Ibn Labbān, the

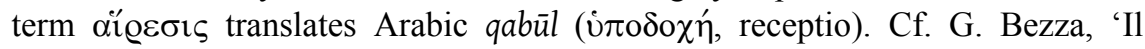
trattato sulle natività di Eleuterio Zebeleno di Elis', $M H N H$ (2002), vol. 2, pp.

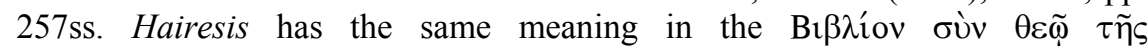

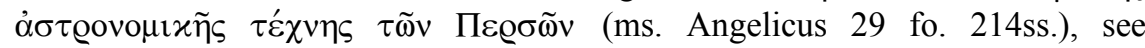
Appendix B. 
248 From Greek hairesis to Arabic hayyiz

dicuntur cum sub signis decurrunt calidis, et que frigide cum sub frigidis, et que humide cum sub humidis, et que sicce cum sub siccis. ${ }^{52}$

The Arabs call 'hayç' the disposition of the star, which we call 'similitude'. For, every star rejoices when it has obtained a place similar to its nature, whether in the world or in the zodiac. For like rejoices in like. Hence also the stars which are seen by day passing through the hemisphere of the day rejoice in the light. But the nocturnal stars rejoice at night. Also, those that are masculine, in masculine signs; feminine in feminine signs; and those that are called 'hot', when they run beneath hot signs, and the cold, when they are under cold signs, the moist under moist, and the dry under dry.

In this statement, two distinct elements of the doctrine are taken into account: the relation between a planet and a portion of time, day and night, and the relation between the gender of the planet, the gender of the various parts of the zodiac and the diurnal motion through the four quadrants which are divided amongst the elemental qualities. ${ }^{53}$

A second term is habitudo. We can find it in a compilation ascribed to Māshā'allāh and in the Liber Alkindi de iudiciis. In these statements, only the first part of the doctrine is considered.

Quod si sue habitudinis locum obtineat, ut diurna de die et econtra quasi qui lucri et prosperitatis sorte splendescit. $^{54}$

Rursum, in stellarum dignitatem ialib, proprietates videlicet aut habitudo stelle, continetur. Dicitur itaque

\footnotetext{
${ }^{52}$ Incipit astronomia magistri Georgij de Anselmis, ms. Vat.lat. 4080, fo. 55r.

53 Among the medieval authors who report this doctrine under the name of similitudo, we can cite: Ibn Ezra (Abrahe Avenaris Iudei astrologi peritissimi in re iudiciali opera...(Principium sapientie), fo. 24ra); John Danko of Saxony, Scriptum super Alchabitium, fo. 48; Bonatti, Decem tractatus de astronomia, II, 3, 15 S. D4r; III, 3, 7, S. E6v; Anonymus Cracoviensis, Ad tabulam quadripartiti, fo. $27 \mathrm{v}$ : 'Et dicunt planete quinque esse in suo haiis hoc est in sua similitudine...'.

${ }^{54}$ Incipit liber Messahala de 14. proprietatibus, fo. $92 \mathrm{r}$.
} 
stelle habitudo locus aliqua portione sibi conveniens. Est namque stellarum pars quedam diei ascripta, pars autem alia nocti dicatur. Si ergo stella diurna de die super terram, nocte quoque sub terram feratur, hec in sua habitudine manere dicetur. Quod si aliter accidat, ab habitudine remotam ponemus. Nocturna item de die sub terram, noctu quoque supra terram moretur, et ipsa suam habitudinem possidet et occupat. Quod si aliter fiat, $a b$ habitudine privatur. $^{55}$

But if it obtains the place of its 'habitude': so that a diurnal star is in a day chart, and vice versa, like one who shines because he has received wealth and prosperity

Again, among the dignities of the stars is included the 'ialib', i.e. the properties or 'habitude' of the star. The 'habitude' of the star is called the place which agrees with it in some proportion. For some of the stars are ascribed to the day, others are dedicated to the night. If, therefore, a diurnal star by day is carried above the earth, and by night under the earth, it will be said to stay in its 'habitude'. But if something different happens, we shall make it far from its 'habitude'. Likewise if a nocturnal star passes the day under the earth, but the night above the earth and holds and occupies its 'habitude'. But if something different happens, it is deprived of its 'habitude'.

This is the first section of the doctrine of hayyiz as a whole and depends on the relationship of the planets with the Sun, i.e. on the phases that occur for the five planets in their synodic cycle. We read in the Isagoge of al-Qabīṣi:

Et planeta cum exierit desub radiis Solis et nulli planete iunctus fuerit, dicitur quod sit in lumine suo. ${ }^{56}$

\footnotetext{
${ }^{55}$ Liber Alkindi de iudiciis, trans. Hugo of Sanctalla, apud al-Qabīṣī, The Introduction to Astrology, p. 393.

${ }^{56}$ Al-Qabīṣ̂, The Introduction to Astrology, III, 10, p. 94.
} 
250 From Greek hairesis to Arabic hayyiz

It is said of a planet that, if it comes out from under the rays $<$ of the Sun $>$ and is not in application with a planet, it is in own light (fi daw' nafsihi). ${ }^{57}$

In this phase, the planet acquires strength ${ }^{58}$ but its strength rests entirely upon its relationship with the Sun. Furthermore, astrologers also say that a planet is in suo lumine when it first appears from the beams of the Sun, the diurnal planet by day, the nocturnal one by night:

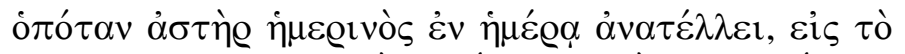

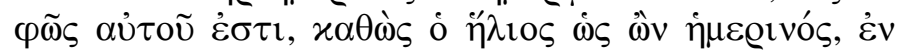

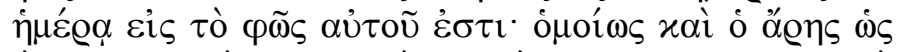

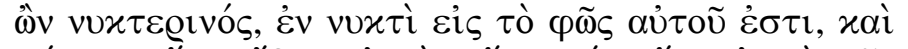

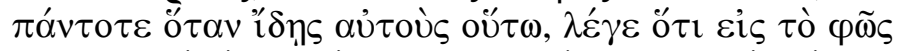

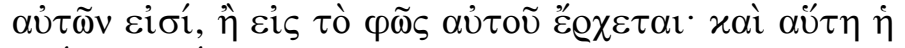
نं

Whenever a diurnal star rises during the day, it is in its own light, as the Sun, which is a diurnal $<$ star $>$, it is in its own light by day; and for Mars, which is nocturnal, its own light is by night; and always, when you see the stars in these conditions, say that they are in their own light or

\footnotetext{
${ }^{57}$ Ibid., p. 302. Cf. John of Eshenden, Summa astrologice iudicialis de accidentibus mundi quce anglicana vulgo nuncupatur (Venice, 1489), fo. 77ra: 'Et planeta cum exierit de sub radiis Solis et nulli planeta iunctus dicitur quod sit in lumine suo et hoc est esse planetarum secundum Alchabitium'; cf. John Danko of Saxony, Scriptum super Alchabitium, fo. 54a.

${ }^{58}$ Cf. Ibn Abī-1-Rijāl, Preclarissimus liber completus in iudicijs astrorum quem edidit Albohazen Haly filius Abenragel, VIII, 33 (Venice, 1485), S. t4rb: ' $\ldots$ et maxime si fuerit orientalis exeundo de sub radijs et existendo in suo lumine levis motus' (about the ruler of the syzygy of each month); Māshā'allāh, In revolutionibus annorum mundi, apud Liber quadripartiti Ptholemei, fo. 149va: 'Cumque sciveris dominum anni et significatorem regis eiusdem regionis, aspice quis eum aspicit et qualis sit fortitudo aspicientis eum et utrum sit in lumine suo i. cum exierit de sub radijs solis et nulli iunctus fuerit vel in lumine alterius', cf. Messahalla ... libri tres ... editi a Ioachimo Hellero (Nuremberg, 1549), ch. 11.
} 
that they are coming into their own light. Therefore the proposed action will take place. $^{59}$

We find the same statement in Sahl ibn Bishr:

De planeta in lumine suo. Dicitur planeta esse in lumine suo, ut Mars cum fuerit in nocte significator, qui est nocturnus, et Saturnus in die dicitur esse in suo lumine, qui est diurnus. ${ }^{60}$

On the planet in its own light. A planet is said to be in its own light, e.g. Mars, which is nocturnal, when it is the significator by night, and Saturn, which is diurnal, when it is by day, are said to be in their own light.

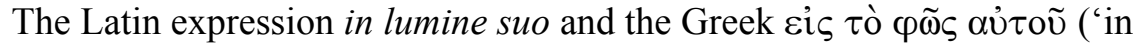
its own light') translate the Arabic fi daw' nafsihi, and 'Alī ibn Riḍān, in his commentary on Ptolemy's Tetrabiblos, misunderstood the Greek word $\lambda \alpha \mu \pi \eta \dot{\eta} \eta$ (chariot) in the context of the doctrine of hayyiz: $\lambda \alpha \mu \pi \eta \dot{v \eta}$ was translated as al-ināra and became synonymous with fi daw' nafsihi. ${ }^{61}$

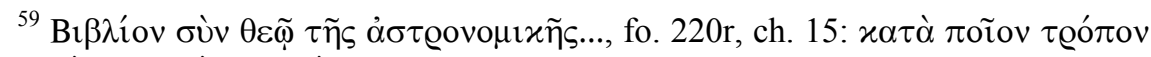

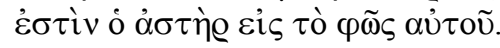

${ }^{60}$ Incipit introductorium de principijs iudiciorum Zahelis Ysmaelite, apud Liber quadripartiti Ptholemei, fo. $125 \mathrm{vb}$; cf. Andalone, fo. $169 \mathrm{v}$, who repeats word by

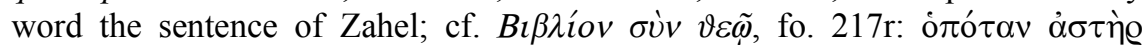

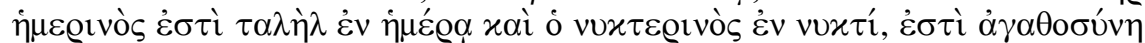

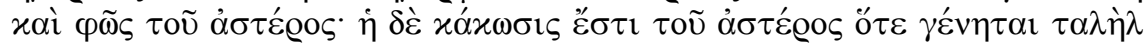

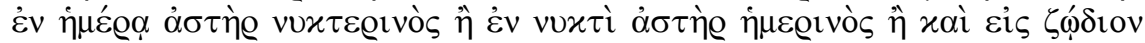

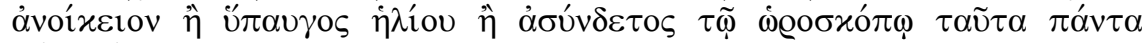

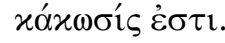

${ }^{61}$ Cf. Liber quadripartiti Ptholemei, fo. 28ra: translation of Plato of Tivoli: 'Hoc autem sequitur alchinara, que fit cum fuerit in sua haiz et in eius simili ex locis sibi convenientibus', cf. trans. of Robert of Chester (ms. Parmensis 719 fo. 320r): 'Dicitur etiam de planetis quod habent alicharam'; cf. Nallino, al-Battān̄ sive Albatenii Opus Astronomicum (Milan, 1903), p. xxi, n. 4: 'Fulgor seu splendor (al-ināra), unde in latina versione Tetrabibli ex arabico alchinara) est pro graeco $\lambda \alpha \mu \pi \eta \dot{\eta} \sim \eta$ i.e. currus seu carpentum regium ... Arabicus interpres

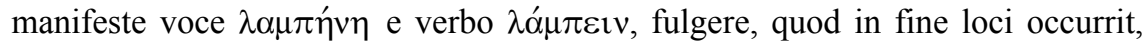

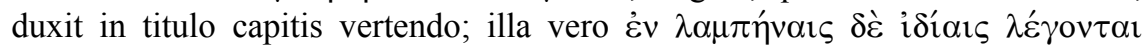

Culture and Cosmos 
In fact, some difficulties arise when astrologers mix together the two distinct elements of the doctrine of hayyiz: one of which depends on the succession of day and night and the other, on the similarity between the gender of the planet and the gender of the zodiacal signs. Sahl ibn Bishr, for example, told us that the planets are in suo lumine when the masculine ones are in the portion of the day and the feminine in the portion of the night. ${ }^{62}$ This statement is ambiguous, because Mars, being masculine, should be in suo lumine during the day, but, being nocturnal, it must be in suo lumine during the night. This difficulty has been apparently resolved by Māshā'allāh when he affirms:

Et scito quod planetæ diurni sunt Sol, Saturnus et Iupiter et masculini in die, et fœminini in nocte. Et planetæ nocturni Luna, Mars et Venus et sunt fominini in die, masculini in nocte. Mercurius autem cum masculis masculinus, cum fœmininis fœmininus, cum nocturnis quoque nocturnus, cum diurnis diurnus est. ${ }^{63}$

Know that the diurnal planets are the Sun, Saturn and Jupiter and they are masculine by day, feminine by night. The nocturnal planets are the Moon, Mars and Venus, and they are feminine by day, masculine by night. Mercury is masculine with the masculine planets, feminine with the feminine, also nocturnal with the nocturnal and diurnal with the diurnal.

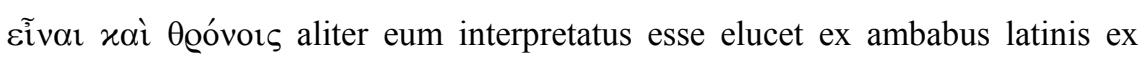
arabico versionibus'. Cf. John of Eshenden, Summa astrologiae, fo. $77 \mathrm{vb}$ : 'Et Ptolemeus primo quadripartiti ca. 23, dicit quod splendor sive illuminatio fit cum fuerit planeta in suo haiz...'; cf. Liber quatuor tractatuum Ptolemei cognomine Alfillud (ms. Paris, Bibliothèque nationale de France, lat.7302, fo. 19v): 'Hec autem sequitur alkinara, i. splendor vel illuminatio'.

${ }^{62}$ See Appendix A. Cf. pseudo-Ahmmad al-Farsī (Angelicus 29, fo. 161v, cap.69; cfr. Palatinus gr. 312, fo. 93v cap. 24 and Marcianus gr. 324, fo. 209v, cap. 24):

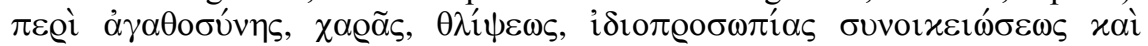

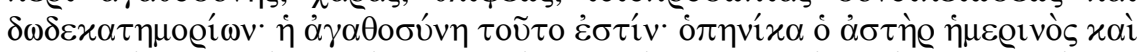

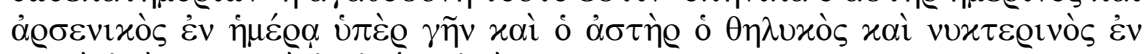

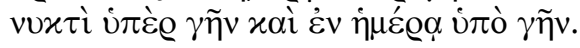

${ }^{63}$ Messahallae... libri tres, ch. 25.

Culture and Cosmos 
We can say, in conclusion, that the term similitudo corresponds to the concept of hairesis on the whole. On the other hand, the expressions in

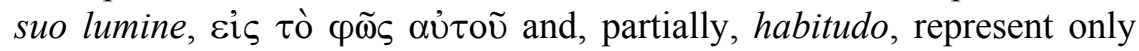
the first section of the doctrine, that concerns the planet's phases of visibility. A superior planet is in its own light at the time of its heliacal morning rising; an inferior planet is in this condition at its heliacal evening rising. Moreover, the superior planet must be above the horizon during the day, the inferior below, and so on. This is the condition that Arabs call jalb or halb:

One of the shares (wa-min al-huzuzz) is the jalb of the planets, i. e. a period related to it. Some of the planets are related to the day, others to the night. And if a diurnal planet is by day above the earth and by night under the earth, it is in its jalb. ${ }^{64}$

Broadly speaking, when the planet enters into a zodiacal sign, it is said to be 'in its hayyiz' or not. When a planet moves through its phases of visibility, both within the synodic cycle and according to diurnal motion, it is said to be 'in its jalb' or not. Thus, the hayyiz happens before the jalb, because its period of time is longer:

The terms hayyiz and halb are related in meaning and they share one condition, namely, that when a diurnal planet is above the earth by day and beneath it at night, and when a nocturnal planet is above the earth at night and beneath it by day, it is said to be in its halb, and a planet in such a state is described as in or not in its halb. When in addition to this a planet is male and in a male sign, or female and in a female sign, the condition is called hayyiz, and a planet is said to be in or not in its hayyiz. Moreover it is obvious that hayyiz is more comprehensive than halb, because every hayyiz is a halb, but not every halb a hayyiz. ${ }^{65}$

\footnotetext{
${ }^{64}$ al-Kindī, Forty Chapters, in: Qabīṣ̄i, The Introduction to Astrology, p. 389.

${ }^{65}$ Al-Bīrūnī, The Book of Instruction, p. 308, §496. I think the word jalb must be preferred to halb. For jalb derives from jalaba, 'to attract, to bring', and it means the act of acquiring or gaining possession. Cf. Abū Ma'shar, Abbreviation, IV, 3: 'In fortuna planetarum (sa'ādat al-kawākib). Or they are swift in their
}

Culture and Cosmos 
254 From Greek hairesis to Arabic hayyiz

\section{Appendix A}

\begin{tabular}{|c|c|c|}
\hline Demophilus & Andalone di Negro & Zahel \\
\hline CCAG 5/4, pp. 226ss. & $\begin{array}{l}\text { Incipit introductorium } \\
\text { valde necessarium ad } \\
\text { iudicia astrologie editum a } \\
\text { domino andolo de nigro de } \\
\text { janua in arte astrologie } \\
\text { peritissimo, ms. BN-Paris } \\
\text { lat. } 7272, \text { fo. } 168 r\end{array}$ & $\begin{array}{l}\text { de interrogationibus, ap. } \\
\text { Liber quadripartiti } \\
\text { Ptholemei..., Venetiis } 1493 \text {, } \\
\text { cc. } 125 \text { ab }\end{array}$ \\
\hline 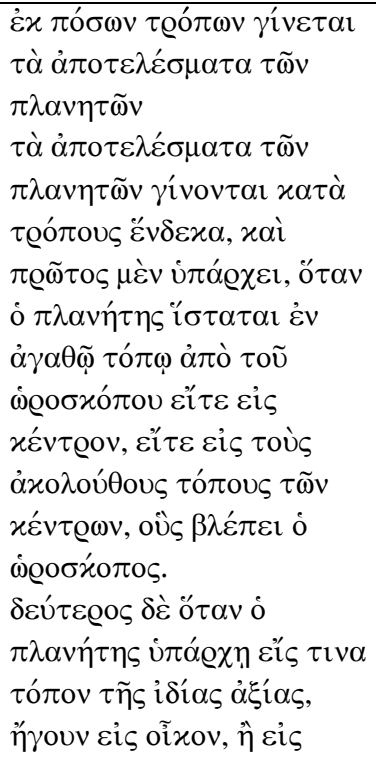 & $\begin{array}{l}\text { De fortitudine } \\
\text { planetarum. Expositio } \\
\text { autem fortitudinis } \\
\text { planetarum cui deest } \\
\text { occasio sive } \\
\text { impedimentum ad } \\
\text { perficiendum causam } \\
\text { cum receperint atque } \\
\text { promiserint fit hoc } 11 . \\
\text { modis. Primo ut sit } \\
\text { planeta in bono loco ab } \\
\text { ascendente i. in angulis } \\
\text { et succedentibus } \\
\text { angulorum ex locis que } \\
\text { aspiciunt ascendens. } \\
\text { Secundo ut sit planeta in }\end{array}$ & $\begin{array}{l}\text { De fortitudine } \\
\text { planetarum } \\
\text { Expositio autem } \\
\text { fortitudinis planetarum } \\
\text { cui deest occasio sive } \\
\text { impedimentum ad } \\
\text { perficiendam causam } \\
\text { cum receperint atque } \\
\text { promiserint; fit hoc } \\
\text { undecim modis. Quorum } \\
\text { primus est ut planeta sit } \\
\text { in bono loco ab } \\
\text { ascendente, i. in angulis } \\
\text { et succedentibus } \\
\text { angulorum ex locis sc. } \\
\text { Qui aspiciunt ascendens. }\end{array}$ \\
\hline
\end{tabular}

motion, increasing in light and number, or they are in their halb, i.e., in the signs in which they have a share (hazz), or in their rejoicings, or in the bright degrees or received, or in their domains (fi hayyizihā)'. Abū Ma'shar, Greater Introduction, VII, 6: p. 304 (= Arabic III, p. 546): 'In fortuna planetarum et eorum fortitudine atque debilitate et detrimento, et in detrimento lune. Et sint velociores cursu, aucti lumine et numero. Aut sint in bonamentis suis ( $f i$ jalbihi), i.e., in domibus suis, vel in exaltationibus aut in terminis vel triplicitatibus seu faciebus suis, aut in gaudiis suis. Aut sint in gradibus lucidis. Aut sint recepti. Vel sint in suo haiz, hoc est ut sit planeta masculinus in signo masculino et gradibus masculinis in die super terram et in nocte sub terra, et femininus in signo feminino et gradibus femininis in die sub terra et in nocte super terram'. Cf. Abenragel, Liber completus, I, 6 (Venice, 1485, fo. 10r): 'Ageleb: aliqui ex eis dicunt quod est haiz (Venice, 1523, fo. vi r: 'haim'; Basel, 1521, p. 19: 'haim'), et alii dicunt quod est dignitas, et primum est veritas et rectum.

Culture and Cosmos 


\begin{tabular}{|c|c|c|}
\hline 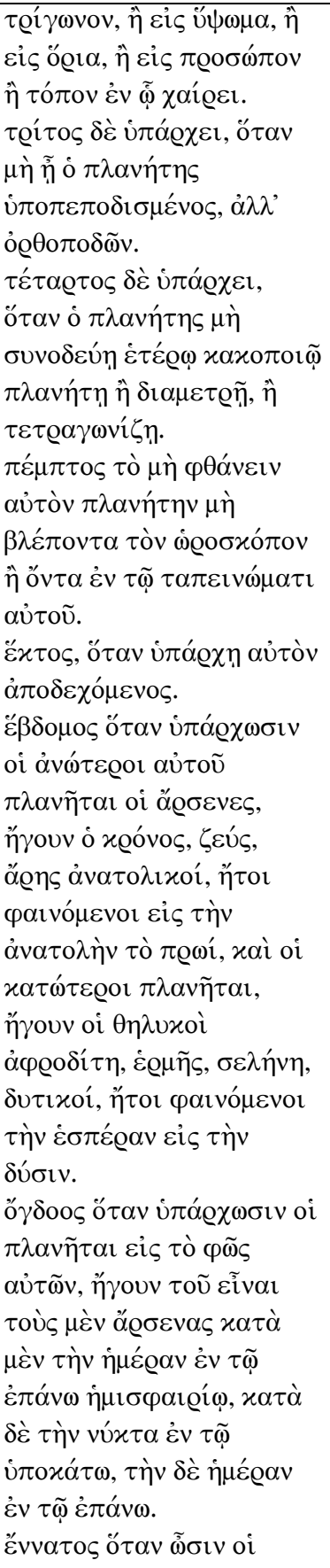 & $\begin{array}{l}m \text { hoc est in } \\
\text { ut non sint } \\
\text { ua aut } \\
\text { el termino } \\
\text { vel gaudio } \\
\text { directus. } 4 . \\
\text { m eo } \\
\text { s, i. in } \\
\text { in quo } \\
\text { it iunctus } \\
\text { b } \\
\text { vel a quarto } \\
t \text { non } \\
\text { le cadenti } \\
\text { e aut } \\
\text { it in }\end{array}$ & $\begin{array}{l}\text { Secundus est ut sit } \\
\text { planeta in aliqua partium } \\
\text { suarum vel dignitatum } \\
\text { hoc in domo sua aut } \\
\text { exaltatione aut } \\
\text { triplicitate vel termino } \\
\text { seu facie sua vel gaudio } \\
\text { suo. } \\
\text { Tertius est ut sit directus. } \\
\text { Quartus ut non sit cum } \\
\text { eo malus planeta, i. in } \\
\text { eodem signo in quo } \\
\text { fuerit cui sit iunctus aut } \\
\text { aspiciat eum ab } \\
\text { oppositione vel a quarto } \\
\text { aspectu. } \\
\text { Quintus ut non iungatur } \\
\text { stelle cadenti ab } \\
\text { ascendente aut planete } \\
\text { qui sit in descensione } \\
\text { sua aut sit ipse in } \\
\text { descensione sua. } \\
\text { Sextus ut sit receptus. } \\
\text { Septimus ut sint planete } \\
\text { altiores masculini, qui } \\
\text { sunt Saturnus, Juppiter et } \\
\text { Mars orientales i. ut } \\
\text { appareant in mane } \\
\text { exeuntes de sub radijs } \\
\text { Solis et planete feminini } \\
\text { i. Venus, Mercurius, } \\
\text { Luna occidentales i. } \\
\text { apparentes vespere. } \\
\text { Octavus ut sint planete } \\
\text { in suo lumine i. sint } \\
\text { planete masculini in die } \\
\text { et feminini in nocte. }\end{array}$ \\
\hline
\end{tabular}


256 From Greek hairesis to Arabic hayyiz

\begin{tabular}{|c|c|c|}
\hline 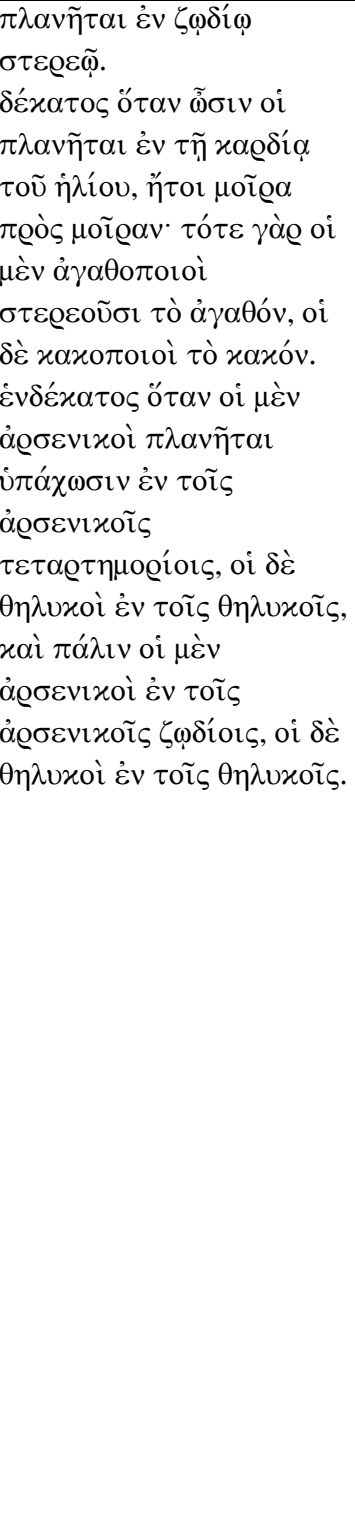 & $\begin{array}{l}\text { Solis, i. cum Sole in uno } \\
\text { gradu quia tunc fortune } \\
\text { augent fortunam et } \\
\text { bonum, mali vero } \\
\text { minuunt malum. 11. ut } \\
\text { sint planete masculini in } \\
\text { quartis masculinis ex } \\
\text { partibus ascendentibus } \\
\text { ex circulo hoc est a } \\
\text { medio celi in ascendente } \\
\text { et a quarto in septimum } \\
\text { directi. Et planete } \\
\text { feminini in quartis } \\
\text { femininis, i. a septimo } \\
\text { in medium celi et ab } \\
\text { ascendente in quartum } \\
\text { directi. Et sint planete } \\
\text { masculi in signis } \\
\text { masculinis et planete } \\
\text { feminini in signis } \\
\text { femininis. Hec enim } \\
\text { sunt testimonia quibus } \\
\text { confortantur planete et } \\
\text { non habent occasionem } \\
\text { que eis noceat ad } \\
\text { perficiendum causam } \\
\text { quando receperunt et } \\
\text { promiserunt. }\end{array}$ & $\begin{array}{l}\text { Nonus ut sint planete in } \\
\text { signis fixis. } \\
\text { Decimus ut sint planete } \\
\text { in corde Solis: cum Sole } \\
\text { in uno gradu quia tunc } \\
\text { fortune augent fortunam } \\
\text { et bonum et malorum } \\
\text { confortatur malum. } \\
\text { Undecimus est ut sint } \\
\text { planete masculini in } \\
\text { quartis masculinis ex } \\
\text { partibus ascendentis ex } \\
\text { circulo, hoc est a medio } \\
\text { celi in ascendente i. a } \\
\text { quarto in septimum } \\
\text { directi ; et planete } \\
\text { feminini in quartis } \\
\text { femininis i. a septimo in } \\
\text { medium celi et ab } \\
\text { ascendente in quartum } \\
\text { directi; et sint planete } \\
\text { masculi in signis } \\
\text { masculinis et planete } \\
\text { feminini in signis } \\
\text { femininis. Hec sunt } \\
\text { testimonia quibus } \\
\text { confortantur planete et } \\
\text { non habent occasionem } \\
\text { que eis noceat ad } \\
\text { perficiendam causam } \\
\text { quando receperint et } \\
\text { promiserint. }\end{array}$ \\
\hline
\end{tabular}

Culture and Cosmos 


\section{Appendix B}

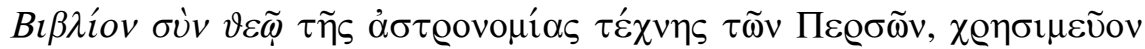

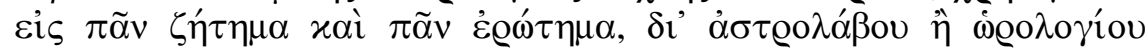

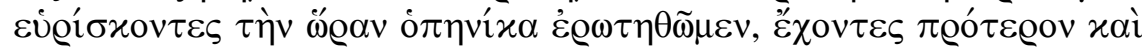

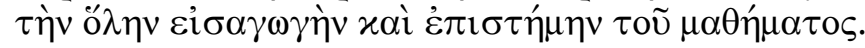

\section{ms. Angelicus 29, fo. 216r-217r}

cap. 4 - Koí $\sigma \varepsilon \imath \varsigma \alpha \dot{\alpha} \sigma \tau \hat{\varepsilon} \varrho \omega v$

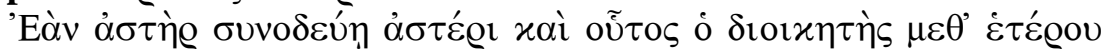

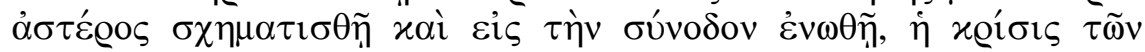

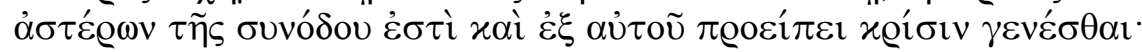

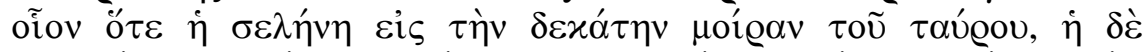

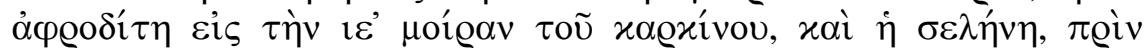

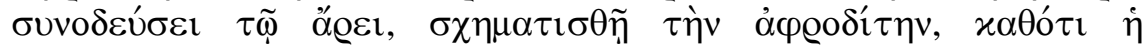

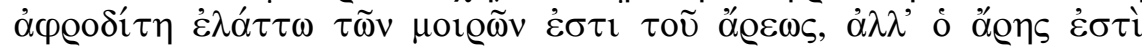

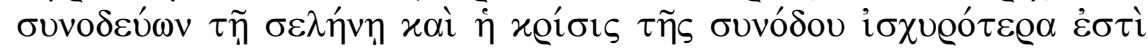

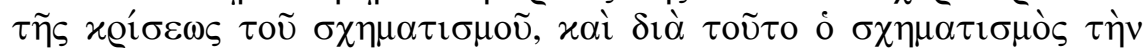

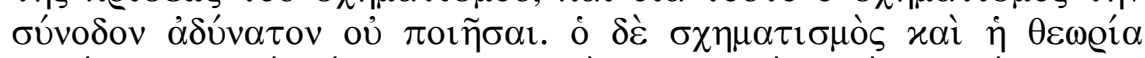

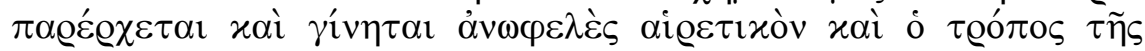

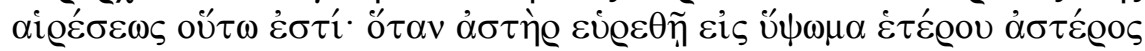

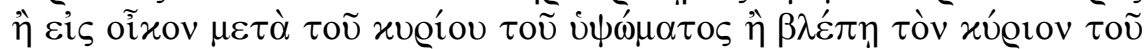

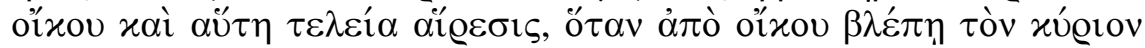

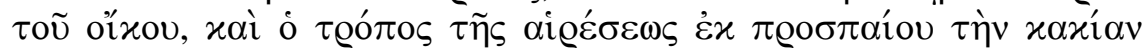

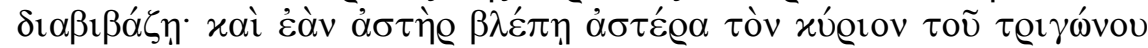

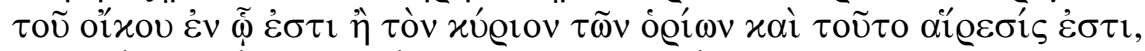

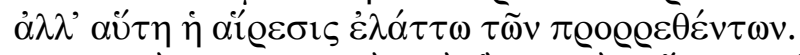

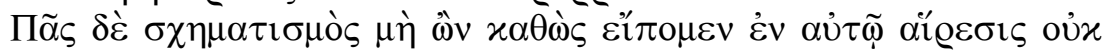

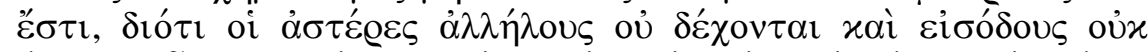

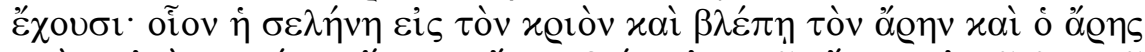

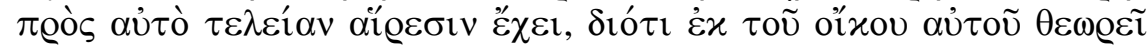

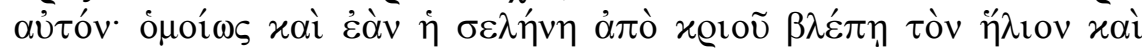

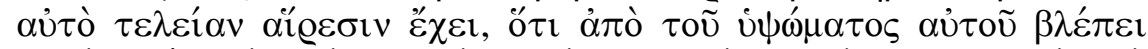

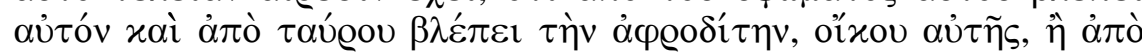

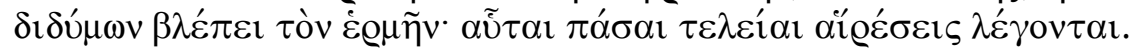

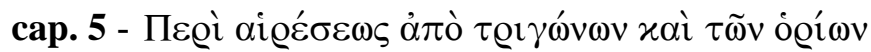

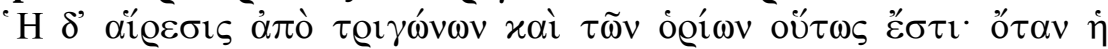

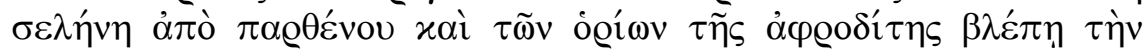

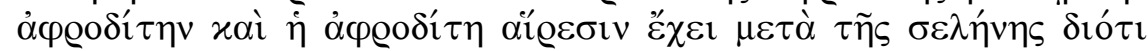

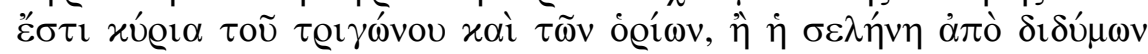




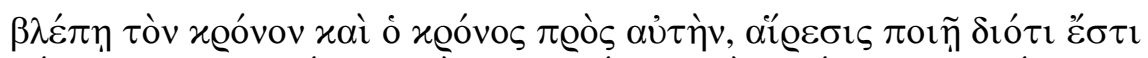

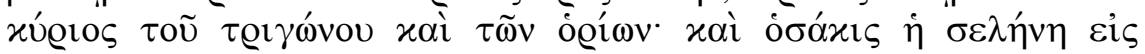

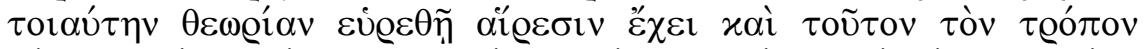

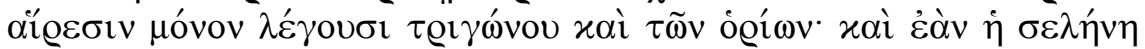

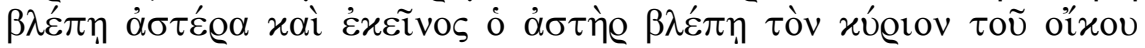

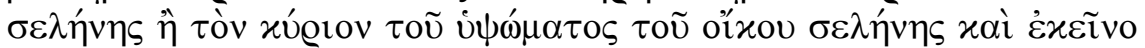

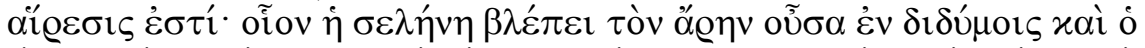

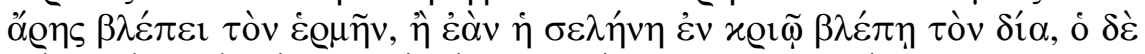

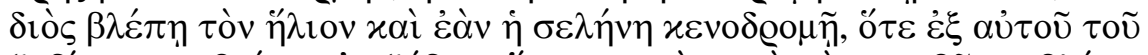

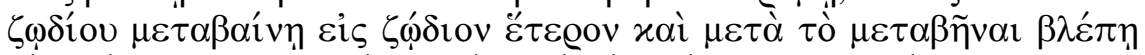

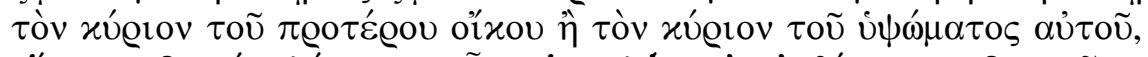

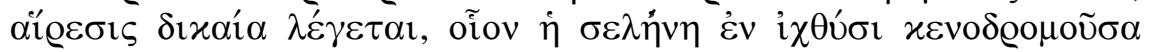

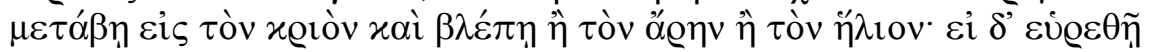

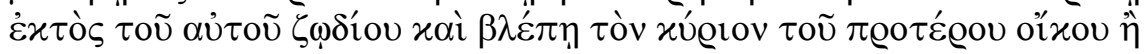

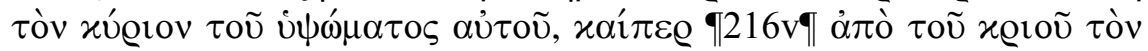

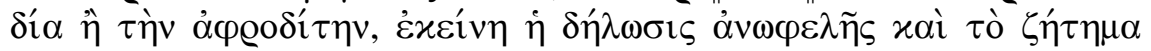

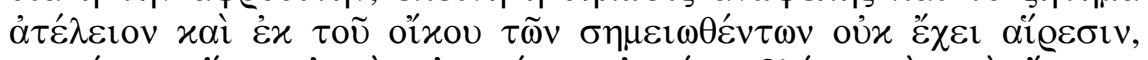

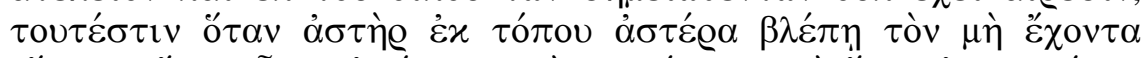

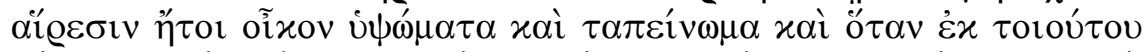

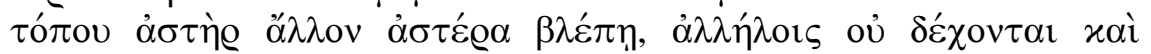

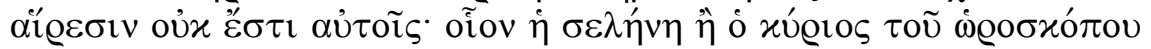

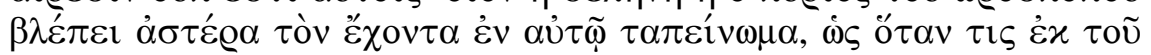

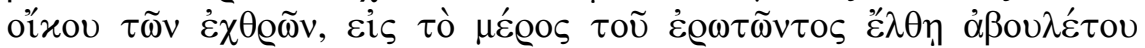

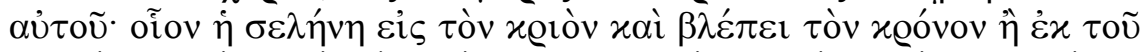

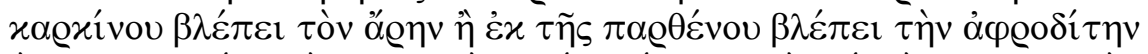

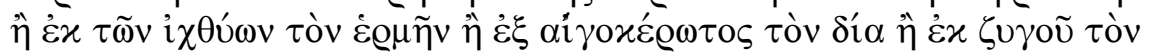

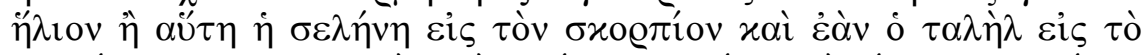

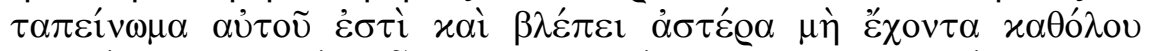

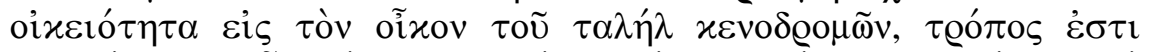

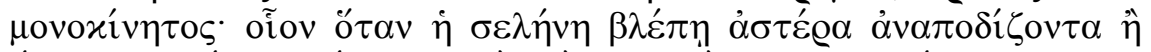

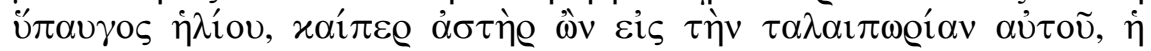

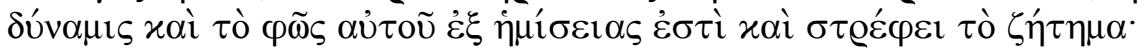

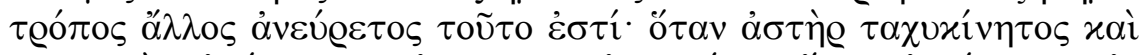

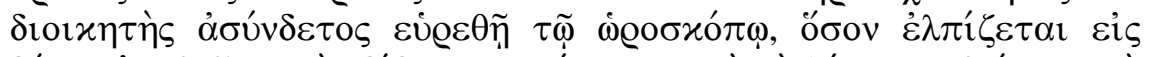

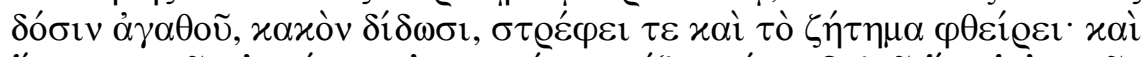

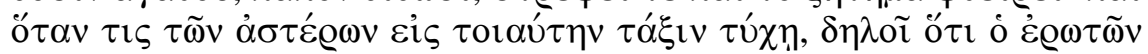

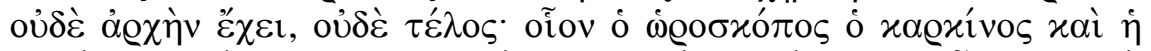

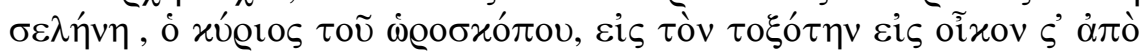

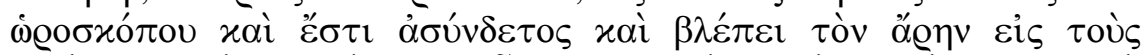

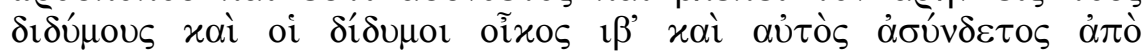

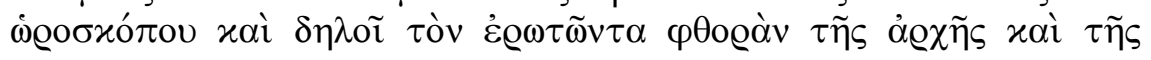




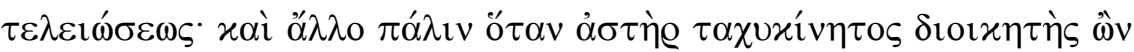

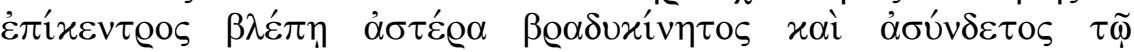

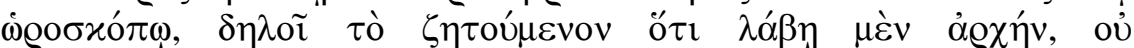

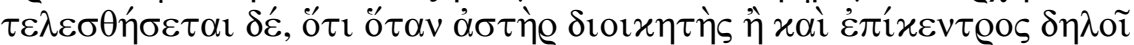

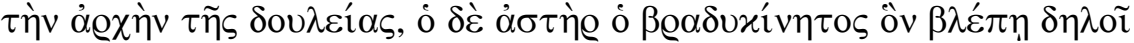

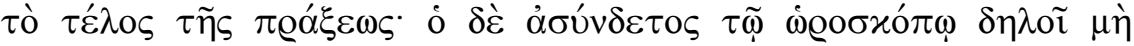

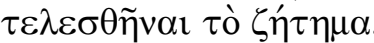

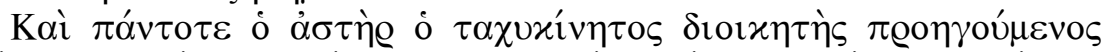

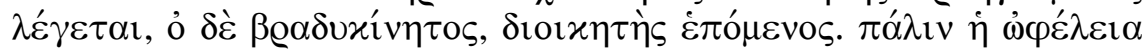

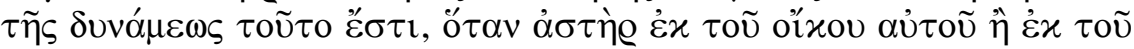

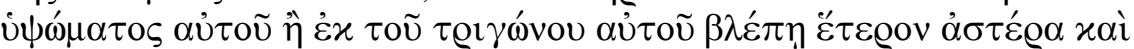

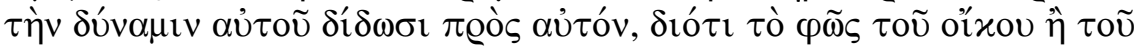

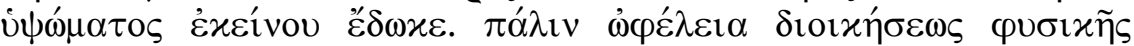

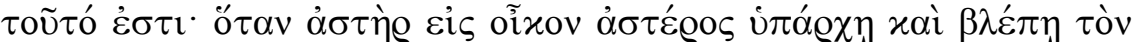

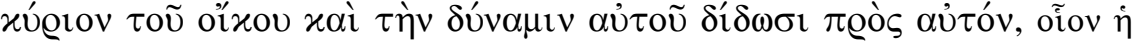

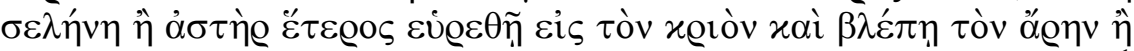

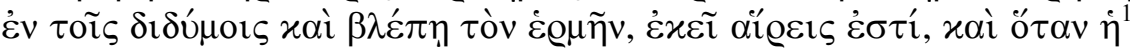

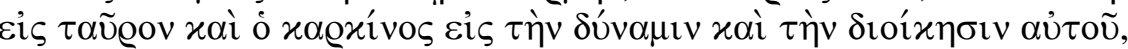

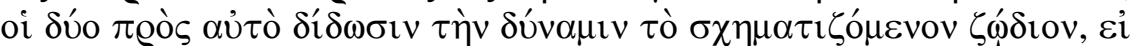

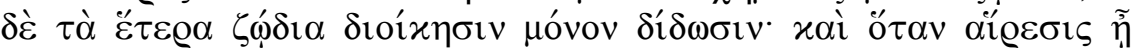

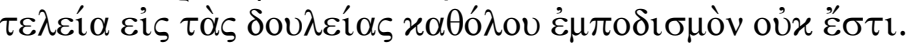

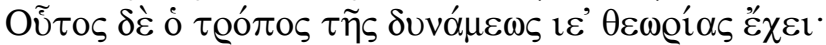

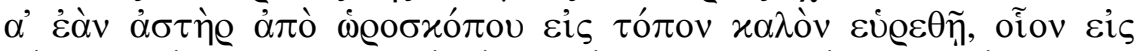

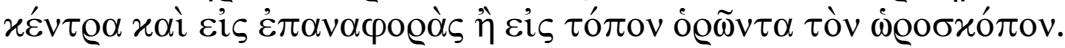

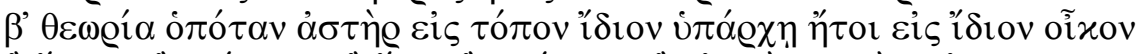

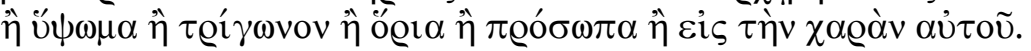

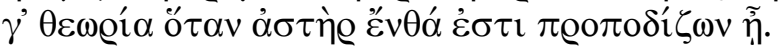

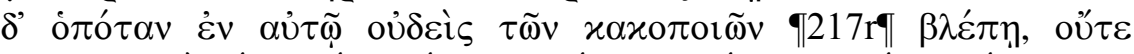

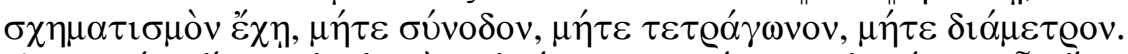

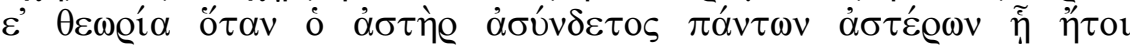

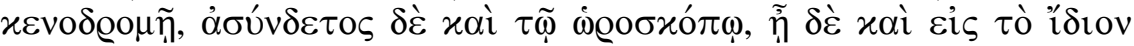
$\tau \alpha \pi \varepsilon^{\prime} v \omega \mu \alpha$.

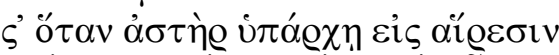

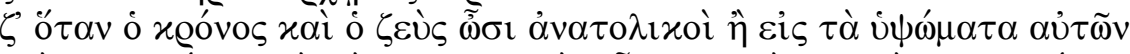

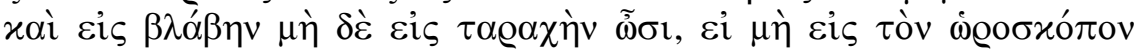

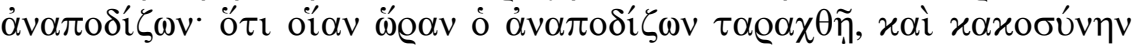

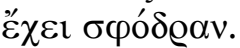

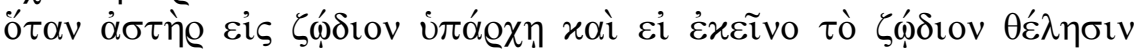

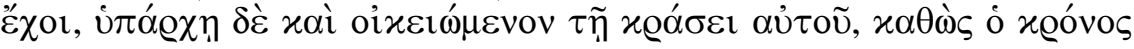

${ }^{1}$ Lacuna unius verbi: $\sigma \varepsilon \lambda \eta \dot{\eta} \eta$.

Culture and Cosmos 
260 From Greek hairesis to Arabic hayyiz

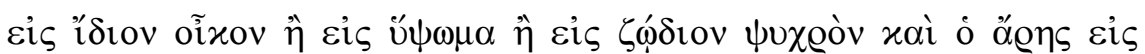

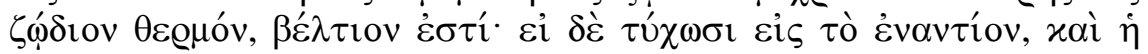

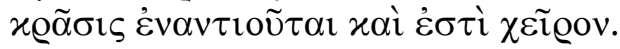

Culture and Cosmos 